Notre Dame Law Review

Volume 75 | Issue 1

Article 3

10-1-1999

\title{
Precedent Lost: Why Encourage Settlement, and Why Permit Non-Party Involvement in Settlements
}

Leandra Lederman

Follow this and additional works at: http://scholarship.law.nd.edu/ndlr

\section{Recommended Citation}

Leandra Lederman, Precedent Lost: Why Encourage Settlement, and Why Permit Non-Party Involvement in Settlements, 75 Notre Dame L. Rev. 221 (1999).

Available at: http://scholarship.law.nd.edu/ndlr/vol75/iss1/3

This Article is brought to you for free and open access by NDLScholarship. It has been accepted for inclusion in Notre Dame Law Review by an authorized administrator of NDLScholarship. For more information, please contact lawdr@nd.edu. 


\title{
PREGEDENT LOST: WHY ENCOURAGE
}

\author{
SETTLEMENT, AND WHY PERMIT NON-PARTY \\ INVOLVEMENT IN SETTLEMENTS?
}

\author{
Leandra Lederman*
}

\section{INTRODUCTION}

Settlement happens. In fact, settlement is the usual outcome of any dispute, and trials are the exception. ${ }^{1}$ Even considering only cases actually docketed, approximately ninety percent settle, ${ }^{2}$ and many additional disputes settle before docketing. Precedent, on the other hand, does not just "happen." A judicial precedent requires not only an aggrieved party who files a lawsuit, but also that the case goes to trial, and perhaps appeal, without a settlement. ${ }^{3}$ A trial may be a "failure," 4 but a trial is a prerequisite to precedent, and precedent is the cornerstone of our common law system. Settlement and precedent are therefore in tension with each other.

* Associate Professor, George Mason University School of Law. A.B. 1987, Bryn Mawr College; J.D. 1990, New York University School of Law; L.L.M. 1993, New York University School of Law. The author would like to thank Bruce Kobayashi, Maxwell Stearns, Todd Zywicki, and workshop participants at Boston University School of Law for their excellent comments; David Hyman and Mark Newton for helpful discussions; Robert S. Taylor for valuable research assistance; and the Law and Economics Center of George Mason University School of Law for financial support.

1 See, e.g., Janet Cooper Alexander, Do the Merits Matter? A Study of Settlements in Securities Class Actions, 43 STAN. L. REv. 497, 498 (1991) (stating that five percent or fewer of litigated cases are tried to judgment) (citing Annual Report of the Director, Administrative Officer of the United States Courts, 1987 REPORTS OF THE ProceEDINGs OF the Judicial Conference of the United States 211); Judith Resnik, Managerial Judges, 96 HARv. L. REv. 374, 405 n.126 (1982) ("Eighty-five to ninety percent of all federal civil suits end by settlement."); $c f$. H. Lee Sarokin, Justice Rushed Is Justice Ruined, 38 RutGers L. REv. 431, 431 (1986) ("The study of law focuses on reported cases, which represent about two or three percent of all suits which are instituted.”).

2 See Alexander, supra note 1.

3 This Article uses the term "precedent" to refer to case law that can influence a later decision in the same court or a lower court.

4 Samuel R. Gross \& Kent D. Syverud, Getting to No: A Study of Settlement Negotiations and the Selection of Cases for Trial, 90 Mrch. L. REv. 319, 320 (1991). 
Litigants control most aspects of litigation and generally control whether and when they settle. Litigants, both actual and prospective, have strong incentives to settle because the costs of litigation so outweigh the costs of settlement. ${ }^{5}$ Given the fact that the overwhelming majority of cases settle, and given the public value of precedent, ${ }^{6}$ one might seek to encourage trials, at least in cases that stand to resolve controversial issues. Instead, courts, commentators, and federal policy seem to favor settlement, ${ }^{7}$ while little attention is given to precedent that may be lost in the process. ${ }^{8}$

The favoritism of settlement is consistent with the view that litigation serves as a dispute resolution mechanism. ${ }^{9}$ Under this view, bringing peace to the parties is paramount, ${ }^{10}$ and precedent created through court decisions is a "mere byproduct" of the dispute resolution process. ${ }^{11}$ As this approach to precedent reveals, the dispute resolution model of litigation focuses on the private costs and benefits of litigation or settlement. Owen Fiss, by contrast, views courts as institutions that help illuminate public values. ${ }^{12} \mathrm{He}$ therefore purports to be "against" settlement. ${ }^{13}$ Of course, each of these views explains only a part of the litigation process. In fact, all litigation has both public and private aspects. ${ }^{14}$ Public money funds courts and pays judges' salaries. Yet, because of justiciability doctrine, most courts, and federal courts in particular, do not decide cases unless there is a live dispute between adverse parties. ${ }^{15}$ An appropriate model of the litigation process should balance both private and public roles in litigation, to illuminate the roles of both precedent and settlement. This Article seeks to develop that model.

Part I of the Article develops the more basic model of the prototypical litigation, in which the parties are the ones who bargain over settlement, and non-parties are not involved. It explores how even in this simple scenario, private and public concerns over settlement and

5 See infra notes 50-51 and accompanying text.

6 Precedent helps non-litigants shape their conduct. People also settle disputes "in the shadow of the law," and that law includes precedent. Robert H. Mnookin \& Lewis Kornhauser, Bargaining in the Shadow of the Law: The Case of Divorce, 88 YALE L.J. 950 (1979).

7 See infra notes 227-30 and accompanying text.

8 But cf. Owen M. Fiss, Against Settlement, 93 YALE L.J. 1073 (1984).

9 See infra notes 18-23 and accompanying text.

10 See infra notes 20-22 and accompanying text.

11 See infra note 23 and accompanying text.

12 See Fiss, supra note 8.

13 See generally id.

14 See infra notes $40-46$ and accompanying text.

15 See infra notes 24-26 and accompanying text. 
precedent conflict. It also examines how settlement nonrandomly affects the substantive content of precedent, as well as the path dependence of precedent.

Part II complicates the model. It considers the question of the proper role of settlement and precedent in litigation influenced by third-party interest groups. This Part considers the effect of thirdparty maneuvering in both Article III cases, using the controversial settlement in Piscataway Township Board of Education v. Taxman ${ }^{16}$ as an example, and in Article I cases, using as an example Smith v. Commissioner, ${ }^{17}$ a tax shelter case involving an unsuccessful third-party attempt to engineer a settlement.

Part $\mathrm{WI}$ of the Article draws on the model developed in Part I, in order to gain insights into the public and private factors in litigation and settlement in Article I courts and in Article III courts. In part, Part III seeks to answer the question of why courts generally encourage settlement, looking at judges' own incentives to encourage settlement, as well as the extent to which the encouragement increases overall efficiency. The Article concludes that we need to balance the importance of precedent against the benefits of settlement when considering whether to have a general approach to encouraging settlement.

\section{Conceptualizing Litigation: Private and Public CONCERNS IN CONFLICT}

\section{A. Theoretical Models of Litigation}

Litigation has traditionally been viewed as a "dispute resolution" mechanism. ${ }^{18}$ "Under the dispute resolution model, a passive, impartial judge settles a self-contained contested transaction between two

16521 U.S. 1117 (1997).

1778 T.C. 350 (1982), aff'd, 820 F.2d 1220 (4th Cir. 1987).

18 See William D. Zellar, Avoiding Issue Preclusion by Settlement Conditioned upon the Vacatur of Entered Judgments, 96 YALE L.J. 860, 871 (1987).

Five elements characterize our 'received tradition' of adjudication. First, the lawsuit is bipolar, engaging two diametrically opposed parties. Second, litigation is retrospective; the dispute concerns discrete, complete, past events. Third, right and remedy are interdependent. Fourth, actions are self-contained: Judgment affects only the two parties and terminates judicial involvement. Finally, litigation is party-initiated and party-controlled.

Id.; see also Fiss, supra note 8, at 1075 ("The advocates of A.D.R. are led to support such measures and to exalt the idea of settlement more generally because they view adjudication as a process to resolve disputes. They act as though courts arose to resolve quarrels between neighbors who had reached an impasse and turned to a stranger for help."). 
private parties-a plaintiff seeking redress for an injury inflicted by a directly adverse defendant." 19 In this view, settlement is a matter of private contract, ${ }^{20}$ a peaceful resolution to a private dispute through negotiated compromise. ${ }^{21}$ Such compromise is instinctively favored over what is in effect a civilized battle between adversaries. ${ }^{22}$ The dispute resolution model views precedent as a "mere byproduct" of the parties' dispute, ${ }^{23}$ minimizing its importance in the calculus of whether to encourage settlement.

Because of the justiciability constraints in Article III courts, ${ }^{24}$ Article III cases generally fit the dispute resolution model of litigation very neatly. ${ }^{25}$ That is, in courts created under the authority of Article III of the Constitution, ${ }^{26}$ evolution of the law occurs only in actual disputes that arise between adverse parties. And in justiciability doctrine, as predicted by the dispute resolution model, third-party concerns about precedent play no role. "Consideration of standing, ripeness and

19 Robert J. Pushaw, Jr., Article III's Case/Controversy Distinction and the Dual Functions of Federal Courts, 69 Notre DAme L. Rev. 447, 458 n.62 (1994).

20 See Margaret Meriwether Cordray, Settlement Agreements and the Supreme Court, 48 Hastincs L.J. 9, 9 (1996) ("American law treats the settlement agreement as a member of the larger family of private contracts.").

21 See, e.g., Marc Galanter \& Mia Cahill, “Most Cases Settle": Judicial Promotion and Regulation of Settlements, 46 STAN. L. REv. 1339, 1371 (1994) ("Settlement typically involves arriving at a position between the original offers and demands of the parties. Thus, it involves a process of compromise in the sense that each has sacrificed some part of his claim in order to secure another part.").

22 Owen Fiss states,

The dispute resolution story makes settlement appear as a perfect substitute for judgment, as we just saw, by trivializing the remedial dimensions of a lawsuit, and also by reducing the social function of the lawsuit to one of resolving private disputes. In that story, settlement appears to achieve exactly the same purpose as judgment-peace between the parties-but at considerably less expense to society.

Fiss, supra note 8 , at 1085 .

23 See Pushaw, supra note 19, at 460 n.62 ("Under the dispute resolution model ... [a]ny law declaration is a mere byproduct of resolving the dispute.").

24 See infra note 26 and accompanying text.

25 See Pushaw, supra note 19, at $447-48$ ("[J] usticiability presupposes that a federal judge's primary function is to resolve disputes, not to declare the law.").

26 U.S. CoNST. art. III, $\$ 2$ ("The judicial Power shall extend to all Cases, in Law and Equity, arising under this Constitution, the Laws of the United States . . . and to Controversies to which the United States shall be a Party ...."). The jurisdiction of a court created under Article III of the United States Constitution is therefore limited to cases and controversies. See id. art. III. The requirement that a case be "justiciable" stems from this clause. See id. 
mootness is made without regard to whether a court's judgment might have collateral benefits to nonparties." 27

From the parties' perspective, the dispute resolution model also fits. Generally, a plaintiff initiates a dispute because he feels he has a right that has been infringed, for which there is a legal remedy. The plaintiff and defendant each consider whether to settle the suit in light of the court's likely ruling should the matter go to trial. ${ }^{28}$ In a nutshell, the reason so many cases settle is because the alternative to settlement is litigation, ${ }^{29}$ which is generally quite costly. ${ }^{30}$ By settling, the parties save the amounts each would have spent to go to trial. This creates a "surplus" that the parties can divide between them, enabling them to reach a settlement that renders each party better off than he would have been had he incurred litigation costs. ${ }^{31}$ The par-

27 Andrea K. Feirstein, Note, Smith v. Commissioner: Unilateral Concessions by Taxpayers, 4 VA. TAX REv. 187, 198 (1984).

$28 C$. Fiss, supra note 8, at 1086 ("[S]ettlement is controlled by the litigants, and is subject to their private motivations and all the vagaries of the bargaining process.").

29 Settlement is inherently tied to litigation, particularly in cases in which suit has been filed. See Alexander, supra note 1, at 500 .

30 See, e.g., No Access to LAw 58 (Laura Nader ed., 1980); Fred WARshofskr, The Patent Wars: The Battle to Own the World's Teghnology 247-48 (1994) (explaining that patent litigation is so costly that its mere threat may prevent a company from forming or from offering a new product); Mauro Cappelletti \& Bryant Garth, Access to Justice: The Newest Wave in the Worldwide Movement to Make Rights Effective, 27 BuFr. L. REv. 181, 186-87 \& n.11 (1978) (stating that studies show that litigation can cost up to one-half of the amount in dispute); Susan S. Silbey, Case Processing: Consumer Protection in an Attomey General's Office, 15 LAw \& Soc'y Rev. 849, 865, 875-76 (1980-81); David M. Trubek et al., The Cost of Ordinary Litigation, 31 UCLA L. Rev. 72, $84 \mathrm{n} .31$ (1983) ("There is substantial evidence that many minor disputes have amounts in dispute less than would be the cost of a lawyer's time to process them.") (citing Stewart Macaulay, Lawyers and Consumer Protection Laws, 14 LAw \& Soc'y Rev. 115, 129-30 (1979), and Silbey, supra, at 865, 875-76); see also Trubek et al., supra, at 113 ("The results strengthen the impression that plaintiffs get a higher return from a strategy oriented to settlement than from one geared toward formal adjudication. Thus the recovery to fee ratio is higher when the attorney spends relatively more time on settlement discussions, but is lower when he devotes relatively more time to legal research.").

31 See Bruce L. Hay, Effort, Information, Settlement, Trial, 24 J. LeGal Stud. 29, 29 (1995) (stating that settling saves litigation costs, so parties can divide surplus created by not litigating); James D. Miller, Using Lotteries to Expand the Range of Litigation Settlements, 26 J. LEGAL STUD. 69, 69 (1997) ("Litigating parties incur deadweight losses that they could avoid if they settled their case."); Steven Shavell, Alternative Dispute Resolution: An Economic Analysis, 24 J. LEGaL STUD. 1, 11 (1995) ("[T] he difference between the plaintiff's expected judgment and the defendant's expected judgment must exceed the sum of their trial costs for there to be a trial; otherwise they will settle to save trial costs. This makes sense, in that the two parties together will save the sum of their trial costs if they settle.") (footnote omitted). 
ties do not internalize costs or benefits to third parties. Thus, the potential precedential value of a court decision will factor into settlement only to the extent that the precedent would have value to one or both parties to the litigation itself. ${ }^{32}$

Owen Fiss's well-known article, Against Settlement, ${ }^{33}$ challenges the dispute resolution litigation paradigm, ${ }^{34}$ propounding an alternative, "public values" view for some types of litigation, ${ }^{35}$ a view that focuses on the role of courts in expounding society's values. ${ }^{36}$ A move away from the dispute resolution paradigm of litigation to an awareness of the "public values" perspective of litigation should entail weighing the parties' interest in settling against the public interest in precedent, although Fiss does not expressly do so. ${ }^{37}$

The "public values" perspective is a minority view that does not seem to have obtained widespread support among courts, ${ }^{38}$ and in fact, it reflects a false dichotomy with the dispute resolution view of

32 Thus, in the economic model of suit and settlement, precedent becomes relevant only where one or both parties is a "repeat player," that is, a repeat litigant on the issue or issues in the case.

33 Fiss, supra note 8.

34 See id. at 1082 ("The dispute resolution story trivializes the remedial dimensions of lawsuits and mistakenly assumes judgment to be the end of the process.").

35 See id. at 1075 ("Settlement is for me the civil analogue of plea bargaining: Consent is often coerced; the bargain may be struck by someone without authority; the absence of a trial and judgment renders subsequent judicial involvement troublesome; and although dockets are trimmed, justice may not be done. Like plea bargaining, settlement is a capitulation to the conditions of mass society and should be neither encouraged nor praised."); see also Owen M. Fiss, The Supreme Court, 1978 Term, Foreword: The Terms of Justice, 93 HARv. L. Rev. 1 (1979); Evan Tsen Lee, Deconstitutionalizing Justiciability: The Example of Mootness, 105 HARv. L. REv. 605, 626 (1992).

36 See Fiss, supra note 8, at 1083 ("The structural reform cases that play such a prominent role on the federal docket provide another occasion for continuing judicial involvement. In these cases, courts seek to safeguard public values by restructuring large-scale bureaucratic organizations."); id. at 1085 ("In my view, however, the purpose of adjudication should be understood in broader terms. Adjudication uses public resources, and employs not strangers chosen by the parties but public officials chosen by a process in which the public participates. These officials, like members of the legislative and executive branches, possess a power that has been defined and conferred by public law, not by private agreement. Their job is not to maximize the ends of private parties, nor simply to secure the peace, but to explicate and give force to the values embodied in authoritative texts such as the Constitution and statutes: to interpret those values and to bring reality into accord with them. This duty is not discharged when the parties settle."). Fiss views settlement as "a highly problematic technique for streamlining dockets." Id. at 1075.

37 See id.

38 This may be because the dispute resolution view is more aligned with judges' interests in encouraging settlement. See infra notes 262-65 and accompanying text. 
litigation..$^{39}$ All litigation includes both private ${ }^{40}$ and public aspects. ${ }^{41}$ That is, most federal litigation requires a private dispute ${ }^{42}$ because Article III courts can generally consider only "live" disputes between adverse parties. ${ }^{43}$ Yet, public resources are used to provide courts-and a court's opinion serves as precedent ${ }^{44}$-a public good. ${ }^{45}$ In fact, "[j] udicial decisions serve two main functions. First, they resolve the immediate dispute between the parties. Second, they often provide some guidance for future conduct." $46 \mathrm{Be}$ that as it may, the dispute

39 See E. Donald Elliott, Symposium on Litigation Management: Managerial Judging and the Evolution of Procedure, 53 U. CHI. L. REv. 306, 325 (1986) ("Rather than argue about which oversimplification [about litigation] is more inaccurate, we should recognize that modern litigation involves a broad spectrum of different kinds of disputes, and therefore that we need a variety of different processes."); Zellar, supra note 18, at 866.

40 See, e.g., William M. Landes \& Richard A. Posner, Adjudication as a Private Good, 8 J. Legal Stud. 235 (1979).

41 See Zellar, supra note 18, at 866 ("Private and public interests coexist as separate preferences in our jurisprudence."). Even Article III of the United States Constitution arguably reflects the public/private distinction in its "case or controversy" requirement. See Robert J. Pushaw, Jr., Congressional Power Over Federal Court Jurisdiction: A Defense of the Neo-Federalist Interpretation of Article III, 1997 BYU L. REv. 847, 864-65 ("The federal courts' principal function in Article III 'Cases' was to expound laws having national and international significance, whereas their main role in 'Controversies' was to act as an impartial arbitrator."); see also Pushaw, supra note 19.

42 See supra note 26 and accompanying text.

43 See supra note 26 and accompanying text.

44 See, e.g., Izumi Seimitsu Kogyo Kabushiki Kaisha v. U.S. Philips Corp., 510 U.S. 27, 40 (1993) (Stevens, J., dissenting) ('Judicial precedents are presumptively correct and valuable to the legal community as a whole. They are not merely the property of private litigants and should stand unless a court concludes that the public interest would be served by vacatur."); Jules Coleman \& Charles Silver, Justice in Settlements, 4 Soc. PHIL. \& Pol'y 102, 114-19 (1986); Henry E. Klingeman, Settlement Pending Appeal: An Argument for Vacatur, 58 FordhaM L. Rev. 233, 234 (1989) ("The decision to grant or to deny vacatur implicates private and public interests that sometimes conflict."); Patrick E. Longan, Congress, the Courts, and the Long Range Plan, 46 AM. U. L. Rev. 625, 662 (1997) ("Without question, the government should subsidize litigation to some extent because private litigants create precedent that enables other litigants to resolve or avoid disputes; thus, that precedent has public value."); David Luban, Settlements and the Erosion of the Public Realm, 83 GEO. L.J. 2619, 2622 (1995) ("[S]ettlements, like private adjudications, produce no rules or precedents binding on nonparties.").

45 See William M. Landes \& Richard A. Posner, Legal Precedent: A Theoretical and Empirical Analysis, 19 J.L. \& Econ. 249 (1976); Luban, supra note 44, at 2623 ("The Landes/Posner/Coleman/Silver analysis shows that precedents and legal rules are public goods. Although the original litigants of the cases "purchase" the rules, future litigants use these rules without paying.").

46 Sarokin, supra note 1 , at 433. A court's decision in a case can also bind a nonparty, in appropriate circumstances, through res judicata or collateral estoppel. See Parklane Hosiery Co. v. Shore, 439 U.S. 322 (1979) (conditionally approving offensive 
resolution view of litigation predominates, perhaps because, as discussed above, it accords both with the viewpoint of litigation parties and with current justiciability doctrine.

\section{B. Bringing Precedent into the Litigation Models}

As discussed above, the dispute resolution model minimizes the importance of precedent in developing litigation policy, by looking at it as a sort of "side effect" of adjudicating a dispute between opposing parties. That view gives less importance to precedent than it deserves because precedent has real power in forming the content of the law. This Section explores how the content of precedent is shaped by party actions. First it explores the effect of the nonrandom nature of settlement on precedent, and then it looks at the effect of path-dependence on the substantive development of precedent.

\section{How Settlement Affects the Content of Precedent}

As discussed above, ${ }^{47}$ precedent does not just "happen." There are two primary factors in the development of precedent: which cases go to trial and therefore result in case precedents, and what the substantive decisions were in prior cases. If settlements occurred randomly, the substantive content of precedent would not be affected by settlements, even if ninety percent of cases were to settle. But settlements are not random because trials are not random. 48 As explained below, ${ }^{49}$ economic analysis of litigation reveals that, where parties act in accordance with the incentive to minimize costs, trials will occur because of party estimation errors or bargaining failures. These trials, nonrandomly selected from the underlying group of cases, will in turn result in nonrandom precedent.

\section{a. Economic Models of Suit and Settlement}

Economic models of settlement assume that the parties derive a settlement amount from the likely amount the court will award if the

use of nonmutual collateral estoppel); Bernhard v. Bank of Am. Nat'l Trust \& Sav. Ass'n, 122 P.2d 892, 898 (Cal. 1942) ("There is no compelling reason, however, for requiring that the party asserting the plea of res judicata must have been a party, or in privity with a party, to the earlier litigation.").

47 See supra notes 3-4 and accompanying text.

48 See Leandra Lederman, Which Cases Go To Trial? An Empirical Study of Predictors of Failure to Settle, 49 CASE W. RES. L. REv. 315 (1999); see also infra notes 49-63 and accompanying text (explaining why trials are not random).

49 See infra notes 59-61 and accompanying text. 
case is tried. ${ }^{50}$ In other words, if the two parties to a case were to agree, for example, that after trial the court will definitely award the plaintiff $\$ 20,000$, but it will cost each side $\$ 4000$ to bring the case to trial, then the parties could save time and money by settling for somewhere between $\$ 16,000$ (what the plaintiff would net from trial) and $\$ 24,000$ (what the defendant would spend in damages plus litigation costs). This simple example illustrates the general principle that where the parties agree on the likely trial outcome, the aggregate of their litigation costs (here $\$ 8000$ ) creates the settlement "surplus" that constitutes the parties' settlement range. ${ }^{51}$

Scholars recognize that this basic economic model of settlement unrealistically assumes, implicitly or explicitly, that the parties have the same estimate of the likely outcome at trial, ${ }^{52}$ are risk-neutral, ${ }^{53} \mathrm{do}$ not engage in strategic behavior in dividing the settlement surplus, ${ }^{54}$

\section{See Shavell, supra note 31.}

51 The basic economic model assumes damages are stipulated and only liability is in dispute. See George L. Priest \& Benjamin Klein, The Selection of Disputes for Litigation, 13 J. LEGAL STUD. 1 (1984). Even if the parties estimate that the plaintiff has less than a $100 \%$ likelihood of being awarded the stipulated damages of $\$ 20,000$, if they agree that damages are $\$ 20,000$, and on the estimated likelihood that those damages will be found by the court, they will still have a settlement range equal to the aggregate of their litigation costs. For example, if the parties agree that the plaintiff has a $70 \%$ likelihood of being awarded $\$ 20,000$, then the statistically expected outcome at trial is $\$ 14,000$. If each party would spend $\$ 4000$ to go to trial, the settlement range is $\$ 10,000$ to $\$ 18,000$. This assumes that the parties are risk-neutral. See infra note 53 .

52 See Gross \& Syverud, supra note 4, at 324 ("[I]f plaintiffs and defendants always agreed in their predictions of trial outcomes, there would be no trials at all.").

53 "Risk-neutral" parties are indifferent between a guaranteed amount, such as a $\$ 14,000$ settlement, and its equivalent expected value, such as a $70 \%$ probability of receiving a \$20,000 award at trial. See Jeffrey M. Perloff \& Daniel L. Rubinfeld, Settlements in Private Antitrust Litigation, in Private ANTITrust Litigation 149, 152 (Lawrence J. White ed., 1988) ("Risk neutral individuals or firms make decisions solely on the basis of the expected return associated with their actions . . . ").

54 Strategic behavior is posturing by a party to capture more of the surplus created by the settlement range. See Gross \& Syverud, supra note 4, at 328; Mnookin \& Kornhauser, supra note 6 . For example, in the example discussed above, see supra text accompanying notes 50-51, the plaintiff was willing to settle for anything over $\$ 16,000$. For strategic purposes, however, he might maintain that he will not settle for anything less than $\$ 18,000$. If the defendant also behaves strategically, perhaps protesting that he would not pay more than $\$ 15,000$, the parties might fail to settle despite the existence of a genuine settlement range between $\$ 16,000$ and $\$ 24,000$. The model also ignores the effects of attorneys, see Ronald J. Gilson \& Robert H. Mnookin, Disputing Through Agents: Cooperation and Conflict Between Lauyers in Litigation, 94 Colum. L. Rev. 509, 512 (1994), and the externalities of court opinions in a precedent-based system, see Bruce H. Kobayashi, Case Selection, External Effects, and the Trial/ Settlement Decision, in Dispute Resolution: Bridging the Settlement Gap 17 (D.A. Anderson ed., 1996) (explaining that trials may occur because the effect of current 
and have no stakes in the litigation other than the economic outcome of the particular case. ${ }^{55}$ It also assumes that settlement costs are zero, ${ }^{56}$ or at least that litigation costs exceed settlement costs by the hypothesized amount, $\$ 4000$ in the example. ${ }^{57}$ If all of these assumptions were in fact true, and if parties made decisions based solely on monetary factors, then the model would predict, unrealistically, that no cases would ever go to trial. Everyone would negotiate a settlement in the range created by the aggregate savings of avoiding trial. As up to ten percent of cases do go to trial, ${ }^{58}$ the strict assumptions of the basic model clearly do not hold true.

This basic economic model therefore serves as a mere starting point to explain why some cases go to trial and others do not. Not surprisingly, scholars have generally explained trials as deviations from the unrealistically strict assumptions of the basic economic model. "Optimism" and "asymmetric information" models each examine the effect of a particular type of deviation from the key assumption of the model that the parties' estimates of the likely outcome at trial are the same. ${ }^{59}$ Trials can also result from deviations from the other assumptions, such as the assumption that parties do not behave strategically in negotiating division of the settlement "surplus."60 All

litigation on future litigation may eliminate a settlement range); Robert D. Cooter \& Daniel L. Rubinfeld, Economic Analysis of Legal Disputes and Their Resolution, 27 J. EcoN. Lit. 1067, 1070 (1989).

55 If a party has reputational stakes in the litigation or is concerned about the precedential effect of a court decision, he will not be motivated by the pure economic concerns of the single litigation. See Kobayashi, supra note 54; Priest \& Klein, supra note 51; see also Frank B. Cross, The Precedent-Setting Value of Litigation and the Selection of Cases for Trial (unpublished paper on file with the author).

56 See Shavell, supra note 31, at 10 ("Trial is assumed to involve a cost for each side, but for simplicity, settlement is taken to be costless.").

57 See Lederman, supra note 48.

58 See supra note 1.

59 See Keith N. Hylton, Asymmetric Information and the Selection of Disputes for Litigation, 22 J. Legal Stud. 187 (1993) (describing a model in which divergent expectations about trial outcomes are based on asymmetric information, suggesting that the "easy" cases go to trial because a party with private information will be eager to settle cases in which he has a weaker than average case); Priest \& Klein, supra note 51 (using a model in which parties' estimates of trial outcome differ because of self-serving "optimism" bias to demonstrate that, if the other assumptions of the basic model remain the same, the "close" cases will disproportionally go to trial).

60 See, e.g., Jeffrey M. Perloff et al., Antitrust Settlements and Trial Outcomes, 78 Rev. ECON. \& Stat. 401, 402 (1996).

Failure to settle may occur for at least three reasons. First, the plaintiff's expected gains may outweigh the defendant's expected losses either because the plaintiff believes its probability of winning is greater than does the defendant, or because the plaintiff expects a larger award at trial than does the 
of these reasons for trials suggest that trials result from some kind of party failure in the bargaining process. ${ }^{61}$

Allowing deviation from the basic model's assumption that the parties' stakes are only those of the particular litigation allows recognition of the role of precedent in explaining trials. If a party to the litigation is concerned about the effect on him of a precedent resulting from the litigation, that party will factor in the expected positive or negative value of the precedent in deciding whether to settle the case. ${ }^{62}$ In other words, if a precedent would save an estimated $\$ 8000$ for the defendant in expected future litigation costs (after factoring in the likelihood that the precedent will be favorable), then the defendant values the potential payout at trial net of the $\$ 8000$ savings, increasing the likelihood of a trial. ${ }^{63}$ Conversely, if avoiding a precedent is worth $\$ 2000$ to a plaintiff, the plaintiff will be willing to accept $\$ 2000$ less in settlement, somewhat decreasing the likelihood of trial. 64

defendant. Second, one or both parties might enjoy taking risks, or their lawyers may have a financial interest in the hours generated by a trial. Third . . "breakdowns" of the settlement bargaining process may occur when parties have informational asymmetries....

$I d$. Risk-seeking behavior can also increase the likelihood of trial. Risk aversion increases the likelihood of settlement because a risk-averse party will prefer a sure outcome, such as a $\$ 12,000$ payment, even if it is less than the statistically predicted (but uncertain) award at trial, such as a 70\% likelihood of a $\$ 20,000$ award (accompanied by a $30 \%$ likelihood of no award at all). Of course the "framing" of options as "wins" or "losses" may affect choices. See Jeffrey Rachlinski, Gains, Losses, and the Psychology of Litigation, 70 S. CAL. L. REv. 113 (1996).

61 See Gross \& Syverud, supra note 4, at 320 ("A trial is a failure.").

62 See Kobayashi, supra note 54.

63 In the example used above, if the defendant expects a 70\% likelihood of a $\$ 20,000$ payment, plus $\$ 4000$ in litigation costs, but will benefit from the precedent by $\$ 8000$, then the defendant's expected cost of trial changes from $\$ 18,000(\$ 14,000$ plus $\$ 4000$ ) to $\$ 10,000$ ( $\$ 14,000$ plus $\$ 4000$ minus $\$ 8000$ ). This will decrease the defendant's maximum offer from $\$ 18,000$ to $\$ 10,000$, reducing the likelihood of settlement.

64 That is, using the same example, if the plaintiff expected to net $\$ 10,000$ following trial ( $\$ 14,000$ expected award minus $\$ 4000$ in litigation costs) but values a precedent as a $\$ 2000$ cost, the plaintiff's minimum demand will decrease from $\$ 10,000$ to $\$ 8000$. Thus, the basic economic model reveals that, where precedent is not an issue, trials result from bargaining failures of some kind that result in elimination of a settlement range. Where trial results because of a party's desire for precedent, however, this analysis suggests that trial is not a failure but rather a purposeful attempt to direct the evolution of the law. See Kobayashi, supra note 54; Paul H. Rubin, Why is the Common Law Efficient?, 6 J. Legal STud. 51, 54 (1977). 


\section{b. The Economic Models' Predicted Effects on Precedent}

Economic theories of suit and settlement each predict a certain selection of cases for trial depending on the explanation for why cases might fail to settle. ${ }^{65}$ For example, Priest and Klein's model, which bases trials on estimation errors caused by party optimism, and adds further assumptions about party estimation errors, ${ }^{66}$ indicates that the "close" cases go to trial. ${ }^{67}$ Priest and Klein's model therefore further implies that the plaintiff will win fifty percent of trials. ${ }^{68}$ However, the model's assumptions are too unrealistic to provide much insight into the content of the resulting decisional precedents. If anything, what decisions under Priest \& Klein's model would do is make clear to the litigants where the "decision standard" that separates the liability zone from the non-liability zone lies. ${ }^{69}$

Priest and Klein also suggest that where there are asymmetric stakes (such as where one party has a greater interest in precedent than the other), trial victory is more likely for the party with the greater stakes. ${ }^{70}$ In general, this means precedents will tend to favor repeat litigants such as institutional defendants. ${ }^{71}$

Similarly, a model that focuses on the importance of precedent to repeat litigants suggests that cases that favor the repeat litigant will be

65 See infra notes 66-76 and accompanying text.

66 The model assumes that the parties' estimation errors are random, independent of each other, normally distributed, with a mean of zero, and homoskedasticthat is, that estimation error does not vary according to how close the case is to the decision standard. See Kobayashi, supra note 54; Lederman, supra note 48.

67 See Priest \& Klein, supra note 51 (noting that cases closest to the "decision standard" in the case go to trial).

68 See id. Priest and Klein assume that damages are stipulated, so the only possible outcome is victory for plaintiff or victory for defendant. See id. at 17. The reason for the " $50 \%$ implication" is that under Priest and Klein's assumptions, the cases that go to trial will disproportionately be those closest to the "decision standard" in the case because the parties' estimation errors will be greater in those cases. See id. Because this means that trials are equally distributed around the decision standard, the judge will find for the plaintiff $50 \%$ of the time.

69 In Priest \& Klein's basic model, damages are stipulated and there are only two possible trial outcomes, liability and non-liability. See id. A particular dispute might have any degree of liability-indicative facts. The "decision standard" is the rule dividing those cases in which the decisionmaker will find the defendant liable from those cases in which he will not. It is therefore implicit in Priest and Klein's model that the decisionmaker will always accurately determine on which side of the decision standard a particular dispute lies. In other words, decisionmaker error is already factored into the location of the decision standard. See Lederman, supra note 48.

70 See Priest \& Klein, supra note 51, at 25.

71 These defendants are less likely to be willing to settle promising cases and more willing to settle cases that look like losers. 
more likely to go to trial. ${ }^{22}$ This suggests that trial precedents are more likely where a repeat player is a party and that such decisions are more likely to favor the repeat player. ${ }^{73}$

Asymmetric information models, by contrast, suggest that the "clear" cases will go to trial, because if a party with private information has information damaging to his case, he will be more willing to settle, thus increasing the settlement range. ${ }^{74}$ This view suggests that cases at the tails of the distribution go to trial and that outcomes will favor the party with the informational advantage. ${ }^{75}$ However, outcomes will move towards less extreme results over time, as error rates fall. ${ }^{76}$

The importance of each of these models to the analysis of the development of precedent is that they suggest that litigation parties, when left to their own devices, will settle cases nonrandomly, which in

72 See Kobayashi, supra note 54.

73 This model opposes the theory that the common law is "efficient," see, e.g., Gregory S. Crespi, The Adequate Assurances Doctrine After U.C.C. \$2-609: A Test of the Efficiency of the Common Law, 38 VILL. L. REv. 179, 179 n.I (1993), that is, that case law evolves toward legal rules that "maximize the aggregate wealth" of parties affected by those rules, see id. at 179 n.l (citing Richard A. POSNER, Economic ANALYsis of LAw $\S 1.2,12-14$ (3d ed. 1986), and Rubin, supra note 64). In the model it is applied to, the current liability rule requires a particular party (such as the defendant) to bear the costs of avoidance and future liability. If the suit is litigated and the plaintiff wins, the liability rule remains the same, so avoidance and liability costs are unchanged. On the other hand, if the defendant wins, the liability rule will be reversed, so that the defendant no longer bears those costs, and the plaintiff must bear them. Under the model, the process will continue, if both sides have a substantial interest in precedents, until the liability rule is on the low-cost avoider, who will find it less expensive to avoid liability than to litigate. Thus, cases that go to trial will disproportionately be those where the law inefficiently places liability on the high-cost avoider.

If the model is correct in predicting which cases will go to trial, and if there is a positive probability that inefficient liability rules will be reversed at trial, this model implies that the law will evolve towards efficiency over time. The evolution towards efficiency implication has been questioned by some scholars. See, e.g., Robert Cooter \& Lewis Kornhauser, Can Litigation Improve Without the Help of Judges?, 9 J. LEGAL STUD. 139, 153-54 (1980) (arguing that such factors as strategic bargaining can cause cases to go to trial whether the resulting precedent is efficient or inefficient); Cooter \& Rubinfeld, supra note 54 (explaining that economic models of legal change demonstrated only a weak tendency towards efficiency); Georg van Wangenheim, The Evolution of Judge Made Law, 13 INr'L REv. L. \& ECON. 381, 382-83 (1993) (arguing that Public Choice theory must be considered in hypothesizing which legal rules are challenged in the judicial process).

74 See James D. Miller, Using Lotteries to Expand the Range of Litigation Settlements, 26 J. LeGal STUd. 69, 72 (1997).

75 See Hylton, supra note 59, at 199.

76 See id. 
turn will influence the substantive content of cases. ${ }^{77}$ At each step along the way, therefore, from docketing through appeal, substantive outcome will in part be determined by nonrandom party choices. Thus, parties' settlement behavior will influence the substantive content of precedent.

\section{The Effect of Path-Dependence on the Development of Precedent}

In a precedent-based system, cases are influenced by those cases that were decided earlier. ${ }^{78}$ That is, our legal system adheres to the concept of stare decisis, standing by things decided. For example, if a precedent is established in Case $A$, and Case $B$ is a similar case that is heard subsequently by the same court or a lower court, Case $B$ will be governed by the holding of Case $A .{ }^{79}$ The outcome in Case $B$ might be different if it is decided after Case $A$ exists as a governing precedent than if Case $B$ were decided first, because Case $B$ might be decided by a judge with different leanings on the issue than the judge who decided Case $A$. Thus, if Case $A$ is decided by Judge $X$, establishing a principle that applies to Case $B$, which later comes before Judge $Y$ on the same court, then Judge $Y$ will likely feel compelled by stare decisis to rule the same way Judge $X$ did-although Judge $Y$ might have ruled the opposite way had he had the opportunity to decide Case $B$ before Judge $X$ had decided Case $A .^{80}$ Precedent is therefore "path-dependent": the order in which cases are presented to a court for decision can influence the substantive content of precedent.

Path-dependence of case law is not limited to courts in which different judges decide different cases. Substantive outcome can be influenced by the ordering of cases even on a court such as the Supreme Court, where the same Justices decide all of the cases. ${ }^{81}$ That is, if the

77 See Theodore Eisenberg, The Relationship Between Plaintiff Success Rates Before Trial and at Trial, 154 J. Royal Star. Soc'y 111, 111 (1991). ("For example, if tried cases contain equal victories for plaintiffs and defendants, one cannot conclude that the applicable legal rules are even-handed. Even if the rules heavily favour the plaintiff, the similar trial success rates are consistent with there being many cases in which plaintiffs recover without going to trial.").

78 Evan H. Caminker, Why Must Inferior Courts Obey Superior Court Precedents?, 46 Stan. L. Rev. 817, 818 \& n.2 (1994). Stare decisis may be accepted by judges because each judge, though preferring to impose his own views, also wants his own decisions to be followed by other judges. See Erin O'Hara, Social Constraint or Implicit Collusion?: Toward a Game Theoretic Analysis of Stare Decisis, 24 Seton HALl L. Rev. 736 (1993).

79 See Caminker, supra note 78 , at 818 \& n.2.

80 See O'Hara, supra note 78.

81 This ignores changes in the composition of the Court that occur over time; a change in the composition of the bench increases path-dependence. 
concept of stare decisis did not exist, the Supreme Court could consider each case anew, which could result in cycling of decisions over time. ${ }^{82}$ Stare decisis prevents that cycling, but at the price of rendering later decisions outcome-dependent on earlier ones. ${ }^{83}$ Precedent is therefore path-dependent regardless of who decides the cases. As discussed below, path-dependence raises the opportunity for intentional path-manipulation targeted to influencing the content of a body of precedent.

\section{Third-Party Involvement in Litigation and Settrlement}

The basic litigation scenario discussed above assumes that the parties control the litigation without the influence of third parties. However, third parties sometimes do become involved in creating or preventing precedents. The path-dependence of precedent creates an opportunity for influence on precedent through manipulation of which cases are presented to a court and the order in which they are presented.

This Part first considers Article III courts, in which path-dependence is somewhat mitigated by justiciability doctrine. It examines how interest groups can manipulate the evolution of precedent in Article III courts in spite of justiciability doctrine. In part, it considers Piscataway Township Board of Education v. Taxman, ${ }^{84}$ in which an interest group manipulated Supreme Court precedent by engineering a settlement of the case. This Part then considers Article I courts, in which justiciability doctrine plays no constitutional role. That discussion focuses on Smith $v$. Commissioner, ${ }^{85}$ a tax shelter case in which a third-party attempt to engineer a settlement was unsuccessful because the court rejected one party's attempt to concede the case in full, requiring the parties to continue litigating.

82 See Maxwell L. Stearns, Standing Back from the Forest: Justiciability and Social Choice, 83 CAL. L. Rev. 1309, 1349 \& n.121 (1995).

83 See id; see also Erwin Chemerinsky, Decision-Makers: In Defense of Courts, 71 AM. BANKR. L.J. 109, 128 (1997) ("Principles of stare decisis serve many valuable ends. First, they enhance efficiency. If appellate precedents are followed, there is no need to litigate the same issue repeatedly in different cases. The question is decided in an appellate court, and lower courts are then responsible for following that decision.").

8491 F.3d 1547 (3d Cir. 1996).

8578 T.C. 350 (1982), aff'd, 820 F.2d 1220 (4th Cir. 1987). 


\section{A. Article III Courts}

Most federal courts are Article III courts, that is, courts that exercise the "judicial Power of the United States" under Article III. ${ }^{86}$ Article III courts include the District Courts, Courts of Appeals, and the Supreme Court. The Constitution restricts Article III courts' jurisdiction to cases and controversies. ${ }^{87}$

\section{Justiciability as a Limitation on Precedent Manipulation}

Absent certain narrow exceptions, Article III courts will not decide "non-justiciable" cases. 88 The bar on deciding non-justiciable cases is derived from Article III's "cases or controversies" clause. ${ }^{89}$ Under the rubric of non-justiciable cases, ${ }^{90}$ these courts will not decide cases that are unripe, ${ }^{91}$ cases in which the plaintiff does not have

86 U.S. CONST. art. III, $\$ 1$; see also Northern Pipeline Constr. Co. v. Marathon Pipe Line Co., 458 U.S. 50, 60 (1982).

87 See U.S. Const. art. III, § 2, cl. 1.

88 An important exception is otherwise "moot" cases that are "capable of repetition, yet evading review." Moore v. Ogilvie, 394 U.S. 814, 816 (1969) (quoting Southern Pac. Terminal Co. v. Interstate Commerce Comm'n, 219 U.S. 498, 515 (1911)). Roe v. Wade, 410 U.S. 113 (1973), is a well-known example of such a case.

89 See, e.g., Honig v. Doe, 484 U.S. 305, 317 (1988) ("Under Article III of the Constitution this Court may only adjudicate actual, ongoing controversies.") (citing Nebraska Press Ass'n. v. Stuart, 427 U.S. 539, 546 (1976)); United States Parole Comm'n. v. Geraghty, 445 U.S. 388, 404 (1980); Preiser v. Newkirk, 422 U.S. 395, 401 (1975); cf. Honig, 484 U.S. at 331 (Rehnquist, C.J., concurring) ("The logical conclusion to be drawn from these cases, and from the historical development of the principle of mootness, is that while an unwillingness to decide moot cases may be connected to the case or controversy requirement of Art. III, it is an attenuated connection that may be overridden where there are strong reasons to override it."). The rationales for mootness doctrine include ensuring adversarial presentation of issues, judicial economy, avoidance of unnecessary litigation, and avoidance of ill-considered opinions based on a poor factual record. See Susan Bandes, The Idea of a Case, 42 StAN. L. Rev. 227, 245 (1990); see also Note, Mootness on Appeal in the Supreme Court, 83 Harv. L. Rev. 1672, 1675 (1970) [hereinafter Mootness] ("Courts [do] not 'waste' their time passing on the merits of 'nondisputes'-controversies for which there is no judicial remedy.") But cf. Bandes, supra at 245 ("[T]o the extent a case is a device to prevent the Court from squandering its resources on nonjudicial tasks, the mootness doctrine presents quite a paradox. As Chief Justice Rehnquist recently observed, the Court's 'unique resources ... are squandered in every case in which it becomes apparent after the decisional process is underway that we may not reach the question presented.' ") (quoting Honig, 484 U.S. at 332 (1988) (Rehnquist, C.J., concurring)).

90 Cases that involve political questions are also non-justiciable. See, e.g., Lea Brilmayer, The Jurispmedence of Article III: Perspectives on the "Case or Controversy" Requirement, 93 HaRv. L. Rev. 297 (1979); Chemerinsky, supra note 83, at 117.

91 A case is not "ripe" if its resolution is legally premature. 
standing, ${ }^{92}$ and cases that have become moot ${ }^{93}$ - and such courts will not issue "advisory opinions." 94

Justiciability doctrine therefore requires an actual injury to the plaintiff, which has matured and which has not been mooted by subsequent events. In fact, all of these limitations are restrictions on the timing of when a court can hear a case. That is, although justiciability doctrine may be applied to preclude a court from hearing a particular case at all, the court may subsequently hear a different case on the same issue. Limiting litigation to "justiciable" disputes provides a certain randomness in that it cannot easily be influenced by interested

92 "Standing" doctrine requires a plaintiff to have a legally cognizable interest in a lawsuit to bring a claim.

93 Mootness doctrine requires a continuing interest in resolution of the lawsuit in order for the court to decide the case. Mootness is "the doctrine of standing set in a time frame." Geraghty, 445 U.S. at 397 (quoting Henry P. Monaghan, Constitutional Adjudication: The Who and When, 82 YALE L.J. 1363, 1384 (1973)).

The Supreme Court has stated that a case is moot when either there is no longer a "live" controversy or the "parties lack a legally cognizable interest in the outcome." Geraghty, 445 U.S. at 396 (quoting Powell v. McCormack, 395 U.S. 486, 496 (1969)). Because a "live" controversy is required, a case can be mooted by settlement, abandonment by the plaintiff of his claim, or by full concession by the defendant. See, e.g., U.S. Bancorp Mortgage Co. v. Bonner Mall Partnership, 513 U.S. 18, 20, 21-22 (1994) ("The parties agreed that confirmation of the plan constituted a settlement that mooted the case. ... If a judgment has become moot [while awaiting review], this Court may not consider its merits, but may make such disposition of the whole case as justice may require.") (quoting Walling v. James V. Reuter, Inc., 321 U.S. 671, 677 (1944)); Lake Coal Co. v. Roberts \& Schaefer Co., 474 U.S. 120 (1985); Deposit Guar. Nat'l Bank v. Roper, 445 U.S. 326, 333 (1980) (“A case or controversy is mooted in the Art. III sense upon payment and satisfaction of a final, unappealable judgment . . . "); California v. San Pablo \& Tulare R.R. Co., 149 U.S. 308 (1893) (holding that the railroad's offer to pay the State the amounts at issue and deposit of the money in a bank mooted the case); Gould v. Control Laser Corp., 866 F.2d 1391, 1392 (Fed. Cir. 1989) (stating that "settlement moots an action"); Tosco Corp. v. Hodel, 826 F.2d 948, 948 (10th Cir. 1987); Lamb v. Commissioner, 390 F.2d 157 (2d Cir. 1968) (dismissing appeal as moot where government tendered full amount sought to be refunded and court was satisfied issue would not recur for subsequent year).

94 See, e.g., Muskrat v. United States, 219 U.S. 346 (1911); Mootness, supra note 89, at 1673 (footnote omitted) ("The prohibition against rendering advisory opinions may be stimulated by the total lack of a factual record, as when a coordinate branch of government makes a request for judicial advice."). But $c f$. Bandes, supra note 89 , at 245 ("This confusion, evident throughout the literature of justiciability, is thrown into sharp relief in the mootness context, in which concrete adverseness once existed, but no longer does. Depending on the stage of the proceedings, concrete factual development continues to be available to assist the Court, and to some degree, adversity continues as well, since at least one of the parties is still willing to litigate.") (citing 13A Charles Alan Wright et al., Federal Practice and Procedure § 3533.1, at 218 (1984)). 
parties. ${ }^{95}$ Thus, justiciability doctrine ameliorates path manipulation by interest groups that could affect the substantive development of the law ${ }^{96}$ by imposing on cases timing limitations that are not entirely within the control of the interested party.

Current justiciability doctrine requires that a case be dismissed if it is nonjusticiable, even if the justiciability problem arises during the pendency of the litigation. ${ }^{97}$ For example, if a case becomes moot, it is dismissed even if the case is nearly ready to be tried. This is not the only possible approach to justiciability doctrine, Chief Justice Rehnquist views mootness doctrine as nonmandatory, merely guided by Article III..$^{98}$ In this view, the Court would have discretion to require parties to litigate a case that had become moot.

\section{Interest-Group Ability to Engineer a Precedent in Article III Courts Despite Justiciability Doctrine}

As discussed above, justiciability doctrine precludes a party desirous of a precedent in a particular area from simply obtaining an advisory opinion or suing in advance of actual injury. ${ }^{99}$ In particular, the requirement that a plaintiff must have standing to sue ${ }^{100}$ helps prevent doctrinal manipulation by interest groups desiring a precedent ${ }^{101}$ because such groups cannot bring suit without having sustained a concrete injury. ${ }^{102}$ Nevertheless, that does not mean that suits are instituted randomly or even haphazardly by injured parties. Although it was not always the case, ${ }^{103}$ interest groups currently have the remedy

\footnotetext{
95 See Stearns, supra note 82 , at 1351,1359 (discussing standing).

96 See id. at 1351.

97 See supra note 89.

98 See Honig v. Doe, 484 U.S. 305, 330 (1988) (Rehnquist, C.J., concurring).

99 See supra note 89 and accompanying text.

100 See supra note 92 and accompanying text.

101 See, e.g., Warth v. Seldin, 422 U.S. 490,498 (1975); Sierra Club v. Morton, 405 U.S. 727 (1972).

102 See supra text accompanying note 99.

103 See Stephen C. Yeazell, Collective Litigation as Collective Action, 1989 U. ILL. L. REv. 43, 52 (" $[\mathrm{T}]$ he common law built barriers between the client and the lawyer. Each of these barriers sought to assure that the client would initiate and finance litigation so he would be neither a free nor a kidnapped rider. The law of barratry forbade the stirring up of quarrels, including the filing of a suit, however meritorious, without the plaintiff's permission. Champerty consisted of agreeing to divide the spoils of a lawsuit, thereby financing litigation that would not otherwise occur. Maintenance consisted of financing another's suit, a form of private legal aid."). Modern law has moved away from prohibitions on barratry, champerty, and maintenance. Modern law allows contingent-fee agreements, which would have been prohibited under champerty rules. See id. at 54. In NAACP v. Button, 371 U.S. 415 (1963), however, the Supreme Court held barratry and maintenance prohibitions unconstitutional as ap-
} 
of seeking out a party who was actually injured and conducting and financing the litigation. ${ }^{104}$ "Test" cases are not considered collusive so long as there was an actual injury to the plaintiff. ${ }^{105}$ This strategy can affect the outcome of the case, in part because the test case can be chosen on the basis of particularly favorable facts. ${ }^{106}$ In addition, interest groups can influence the order that cases reach the Supreme Court, ${ }^{107}$ which, as discussed above, can affect case outcomes. ${ }^{108}$

Justice Thurgood Marshall's approach on behalf of the NAACP to obtaining victory in Brown v. Board of Education, ${ }^{109}$ which overruled the "separate but equal" doctrine of Plessy $v$. Ferguson, ${ }^{110}$ is an excellent example of such a successful strategy. ${ }^{111}$ Rather than attacking Plessy directly, Justice Marshall executed a well-planned series of steps designed to chip away incrementally at the "separate but equal" rule

plied to the NAACP, finding the NAACP litigation a form of political expression. See $i d$. at 429-31. The case involved the Virginia Conference of the NAACP, which focused on "financing litigation aimed at ending racial segregation" in Virginia public schools. Id. at 420 \& n.4. The Virginia Conference generally financed cases in which the plaintiff retained an NAACP staff attorney, but sometimes financed other cases. See id.

104 See John Howard, Retaliation, Reinstatement, and Friends of the Court: Amicus Participation in Brock v. Roadway Express, Inc., 31 How. L.J. 241, 254 (1988) ("Litigation is not an uncommon interest group tactic. Most notable for handling cases from trial through the appellate level are groups such as the National Association for the Advancement of Colored People (NAACP) and the American Civil Liberties Union (ACLU). These organizations identify potential abuses and orchestrate implementation of their goals through carefully-managed test cases, becoming, in effect, the real party in interest.").

105 See Button, 371 U.S. at 429-31 (1963); see also supra note 101; cf. Havens Realty Corp. v. Coleman, 455 U.S. 363 (1982) (holding that a black "tester," an employee of Housing Opportunities Made Equal, who was given false information about housing availability, had standing to challenge racial steering under section 812 of the Fair Housing Act because section 804(d) of that Act made misrepresentation as to the availability of a dwelling unlawful).

106 See Gerald L. Neuman, Variations for Mixed Voices, 137 U. PA. L. Rev. 1851, 1866 n.61 (1989) (reviewing Louis Fisher, Constrtutional Dialogue as Polttical Process (1988)) ("The direction of doctrinal development in a system that includes a norm of precedent is substantially path-dependent. Lawyers attempt to exploit this characteristic in their strategic choice of plaintiffs and defendants . . ..").

107 Nat Hentoff, Victim of Affirmative Action, Village VoIce, Jan. 6, 1998, at 20 ("Thurgood Marshall prepared his cases very carefully, structuring a dynamic of lower-court cases so that when he got to the Supreme Court with Brown v. Board of Education, the door was open."). Justice Marshall's strategy is discussed in further detail below. See infra notes 110-21 and accompanying text.

108 See supra notes 78-83 and accompanying text.

109347 U.S. 483 (1954).

110163 U.S. 537 (1896).

111 See Stearns, supra note 82, at 1364-66. 
of Plessy. ${ }^{112}$ The NAACP started at the graduate school level, where the challenge was least likely to be opposed by whites and most likely to be successful. ${ }^{113}$ The first case the NAACP brought to implement this strategy was Pearson v. Murray, ${ }^{114}$ involving a challenge from a black man who had been denied admission to Maryland Law School. ${ }^{115}$ The NAACP found "an ideal [plaintiff] - . . a twenty-yearold Baltimore resident who had graduated from Amherst ...--[a] well-qualified, nice-looking fellow from a prominent black family." 116 Having achieved victory at the appellate level, the NAACP brought Missouri ex rel. Gaines v. Canada ${ }^{117}$ to the Supreme Court. In that case, the Court ordered the State of Missouri to either admit blacks to the existing white law school or to provide an in-state law school for blacks; this was the NAACP's first major Supreme Court victory. ${ }^{118}$ It was followed by NAACP victories in Sipuel v. Board of Regents, ${ }^{119}$ Sweatt v. Painter, ${ }^{120}$ and McLaurin v. Oklahoma State Regents. ${ }^{121}$ These successes set the stage for the NAACP's important victory in Brown $v$. Board of Education ${ }^{122}$ in 1954, which required integration of elementary schools. Without the earlier favorable precedents, the Brown result would likely not have been possible. ${ }^{123}$

The ACLU and Justice Ruth Bader Ginsburg followed a similar strategy in seeking heightened scrutiny protection for women under the Equal Protection Clause of the Fourteenth Amendment. ${ }^{124}$ After winning Reed v. Reed, ${ }^{125}$

112 See id.

113 See id. at 1365 n.165.

114182 A. 590 (Md. 1936).

115 See Stearns, supra note 82, at 1365 n.166.

116 Richard Kluger, Simple Justice: The History of Brown v. Board of Education AND Black AMErica's Struggle for EQualtTy 187 (1975).

117305 U.S. 337 (1938).

118 Daniel Gyebi, A Tribute to Courage on the Fortieth Anniversary of Brown v. Board of Education, 38 How. L.J. 23, 34 \& n.60 (1994).

119332 U.S. 631 (1948) (requiring Oklahoma to provide an equal law school education to a woman denied admission to the University of Oklahoma because she was black).

120339 U.S. 629 (1950) (requiring admission of qualified blacks to the University of Texas Law School).

121339 U.S. 637 (1950) (prohibiting the University of Oklahoma from requiring a black graduate student to sit physically separated in the classroom, to use separate tables outside the library, and to eat at separate times in the school cafeteria).

122347 U.S. 483 (1954).

123 See Stearns, supra note 82, at 1366.

124 See id.

125404 U.S. 71 (1971). 
the ACLU established the Women's Rights Project, and Ginsburg became its first director. In this role, her strategy in bringing cases to the Supreme Court had several components. First, she pursued an incremental approach, whereupon she would build "precedents one upon the other." Similarly, she chose cases with easily understandable issues that could be clearly won "which would lay the precedential groundwork for more difficult problems."126

The strategy of picking cases with favorable facts and sympathetic plaintiffs explains how interest groups can rely on the path-dependence of precedent to influence the development of the law despite standing doctrine. In effect, interest groups can weight both the pool of docketed cases by picking cases with favorable facts and the pool of which cases go to trial by being unwilling to settle these favorable cases. That is, neither Justice Marshall nor Justice Ginsburg sought "dispute resolution" in the traditional sense, ${ }^{127}$ but rather they sought helpful precedents to further their causes. The interests of the nominal plaintiffs in the cases they litigated were not the motivation; instead the motivation was the interests of the larger group to which the plaintiffs belonged. ${ }^{128}$ Thus, despite the restrictions of the justiciability doctrine discussed in Section B, interest groups desirous of precedents can bring cases to court for the express purpose of precedent creation. These cases are unlikely to settle because, in the language of the economic model discussed in Part I, Section $A,{ }^{129}$ the parties have such unequal stakes that a settlement range does not exist. That is, the interest group is unlikely to settle regardless of any offer made by the defendant because its goal is to obtain a favorable precedent.

\section{Interest-Group Ability to Avoid Precedent by Engineering a Settlement}

Interest groups do not influence the substantive content of precedent only by selecting specific cases to litigate. Although less common, interest groups can also help settle cases they believe would result in precedent harmful to their cause. ${ }^{130}$ Piscataway Township

126 Joyce Ann Baugh et al., Justice Ruth Bader Ginsburg: A Preliminary Assessment, 26 U. ToL. L. REv. 1, 25-26 (1994) (quoting Deborah L. Markowitz, In Pursuit of Equality: One Woman's Work to Change the Law, 11 Women's RTs. L. REP. 73, 75, 83, 97 (1989)).

127 See supra text accompanying note 9.

128 See supra notes 107-26 and accompanying text. NAACP v. Button, 371 U.S. 415 (1963), permits this kind of litigation. See supra note 103.

129 See supra note 55 and accompanying text.

130 Another technique that has been widely discussed is settlement pending appeal contingent on a joint motion for vacatur of a lower court's decision. See, e.g., 
Board of Education v. Taxman ${ }^{131}$ is a well-known and controversial example of an interest group "engineering" a settlement.

\section{a. The Piscataway Story}

The Piscataway case arose out of a layoff in Piscataway, New Jersey. The Piscataway School Board, faced with budget cuts, selected Sharon Taxman for layoff. ${ }^{132}$ Ms. Taxman, who is white, and Debra Williams, who is black, had commenced employment the same day and were the most junior teachers in the department. ${ }^{133}$ Because the two teachers had equal seniority and they were determined to be of equal ability and qualifications, ${ }^{134}$ the school board needed a tiebreaker in deter-

Howard Slavitt, Selling the Integrity of the System of Precedent: Selective Publication, Depublication, and Vacatur, 30 HARv. C.R.-C.L. L. Rev. 109, 136 n.173 (1995) ("While it is impossible to know why a losing party would want to vacate a particular opinion, the institutional litigant's likely motive was to erase negative precedent."). The scholarly outcry appropriately reflects the view that precedents are public, and therefore not subject to the parties' private agreement. See, e.g., Daniel Purcell, The Public Right to Precedent: A Theory and Rejection of Vacatur, 85 CAL. L. Rev. 867, 887 (1997) ("Vacatur typically comes out of an agreement between the parties, hardly an adversary tactic. Instead, the repeat player uses vacatur "against" the public in general, the larger body of future possible litigants, by depriving them of favorable precedent on which to rely. When vacatur is understood in this way-as a means of controlling future consequential damages resulting from an adverse finding-the adversary party in the current litigation becomes irrelevant."); see also David M. Staker, Comment, The Use of Lower Court Judgments as Bargaining Chips: Should Courts Routinely Grant Vacatur When Parties Settle Pending Appeal?, 43 U. KAN. L. Rev. 233, 242 (1994) ("By converting the judgment into a bargaining chip in the process of settlement, vacatur 'clouds and diminishes' the value of precedent.") (citation omitted). A detailed discussion of settlement contingent on vacatur is beyond the scope of this Article.

131521 U.S. 1117 (1997).

132 At the time of layoffs, each teacher had nine years of seniority in typing and secretarial studies. See United States v. Board of Educ., 832 F. Supp. 836, 840 (D.N.J. 1993). With respect to general bookkeeping and accounting, Ms. Taxman had nine years of seniority, and Ms. Williams had four years and three months of seniority. See id.

133 See Jan Crawford Greenburg, Civil Rights Groups Pay Teacher to Avoid Court, CHr. Trib., Nov. 22, 1997, § 1, at 1 .

134 See Taxman v. Board of Educ., 91 F.3d 1547, 1551 (3d Cir. 1996). Ms. Williams had a masters degree, and Ms. Taxman did not, but the courts did not discuss the relevance of the additional degree in the comparison of qualifications. See Yvonne Scruggs-Leftwich, Not a Case of Affirmative Action, WASH. Post, Dec. 13, 1997, at A21. Ms. Taxman apparently had two more years of teaching experience than Ms. Williams so the Piscataway School Board deemed their qualifications equal. See Paul Shepard, Issue One That Isn't Going Away, Chatranooga Times, Nov. 22, 1997, at A5. 
mining whom to lay off. Normally, the school flipped a coin. ${ }^{135}$ In this case, however, Piscataway used its affirmative action policy as a tiebreaker. ${ }^{136}$ Although blacks were not underrepresented in the school as a whole, ${ }^{137}$ Ms. Williams was the only black teacher in the department so Ms. Taxman was the one chosen for layoff. ${ }^{138}$

Ms. Taxman filed a charge of employment discrimination with the Equal Employment Opportunity Commission. ${ }^{139}$ When the case was not resolved administratively, the United States sued the school board under Title VII of the Civil Rights Act of 1964,140 and Ms. Taxman intervened, suing under both Title VII and the New Jersey Law Against Discrimination. ${ }^{141}$ The district court granted partial summary judgment on the issue of liability in favor of the United States and Ms. Taxman. ${ }^{142}$

By the time of trial on the issue of damages, the school board had reinstated Ms. Taxman. ${ }^{143}$ The district court awarded Ms. Taxman $\$ 134,014.62$ for back pay, fringe benefits, and prejudgment interest under Title VII, and the court ordered the school board to give Ms. Taxman full seniority reflecting continuous employment from the time she was originally hired. ${ }^{144}$ A jury awarded Ms. Taxman an additional $\$ 10,000$ for emotional suffering under the New Jersey Law Against Discrimination. ${ }^{145}$

The school board appealed, and Ms. Taxman cross-appealed on the denial of her punitive damages claim. ${ }^{146}$ In a nine to four decision, the Third Circuit found the school board liable. Importantly,

135 See Simon Barber, Settlement to Blow Affirmative Action, Bus. DAY (S. AFr.), Nov. 27,1997 , at 15 ("If they had both been of the same race, the board later conceded the issue would have been decided by the toss of a coin.").

136 See id. The affirmative action policy had been adopted in 1983. See id.

137 See Taxman, 91 F.3d at 1563.

138 See Board of Education, 832 F. Supp. at 840.

139 See Taxman, 91 F.3d at 1552.

14042 U.S.C. $\$ 2000 \mathrm{e}-1-\mathrm{e}-17$ (1994).

141 See Board of Education, 832 F. Supp. at 836.

142 See id. at 851.

143 See Taxman, 91 F.3d at 1552.

144 See id.

145 See id.

146 See id. On appeal, the United States was no longer a party to the case. See id. As a result of a change in administrations, the Justice Department apparently changed its substantive position in the case, arguing that Piscataway's approach was Constitutional. See Russ Bleemer, Court Bars DOJ from School Board Case, Legal Times, Nov. 27, 1995, at 19; Russ Bleemer, Sloviter Will Be Tie-Breaker in Discrimination Case, N.J. L.J., Nov. 6, 1995, at 3. The Clinton administration then changed tacks, urging the Supreme Court to rule narrowly in favor of Ms. Taxman. See Greenburg, supra note 133 , at 1. 
the court stated, "Although we applaud the goal of racial diversity, we cannot agree that Title VII permits an employer to advance that goal through non-remedial discriminatory measures." 147

The school board petitioned the Supreme Court for certiorari, and the petition was granted. ${ }^{148}$ Civil rights groups feared that Piscataway could lead to a broad Supreme Court ruling that diversity is never an acceptable motive for a racial preference. ${ }^{149}$ The groups offered the school board $\$ 300,000$ towards a settlement with Ms. Taxman, in order to avoid a potentially damaging Supreme Court decision. Two months before the scheduled oral argument, ${ }^{150}$ the school board settled with Ms. Taxman for $\$ 433,500 .{ }^{151}$ The board reported that it settled the case to avoid publicity and because it thought it was best for the town. ${ }^{152}$ The board also stated that it had accepted the $\$ 300,000$ from civil rights groups to appease local taxpayers. ${ }^{153}$

$147 I d$. at 1567.

148 See Piscataway Township Bd. of Educ. v. Taxman, 521 U.S. 1117 (1997).

149 See Greenburg, supra note 133, at 1 ("'The fear is that the Supreme Court in recent times has been rather hostile to affirmative action,' said Antonia Hernandez, president and general counsel of Mexican American Legal and Educational Defense Fund, or MALDEF, which supported the school board. 'The concern was this case was going to be more of a vehicle for destroying what's left of affirmative action, rather than dealing with the facts of the case and allowing civil rights lawyers to put the best case forward.'") (citation ommitted); see also Hentoff, supra note 107, at 20 ("[Debra Williams] was also abandoned, of course, by Jesse Jackson, Hugh Price of the National Urban League, and Kweisi Mfume of the NAACP, among other members of the Black Leadership Forum. They felt they had urgent responsibilities to blacks in the mass because the Piscataway case looked like a sure loser. And the Supreme Court could bring down many affirmative action gains in hiring and admissions throughout the country."); Kathleen M. Sullivan, Supreme Court Avoidance; On Piscataway, Strategy and the High Court, WAsh. Post, Dec. 7, 1997, at Cl.

150 Oral argument had been scheduled for January 14, 1998. See Paula Alexander Becker, Affirmative Action and Reverse Discrimination: Does Taxman v. Board of Education of the Township of Piscataway Define the Outer Limits of Lawful Voluntary RaceConscious Affirmative Action?, 8 Seton HALl Const. L.J. 13, 15 n.14 (1997).

151 See Melissa Henneberger, On Race, an Optimist in an Unlikely Place, N.Y. Times, Dec. $14,1997, \S 14$, at 2 . Of the settlement, Ms. Taxman received $\$ 186,000$, which reflects the $\$ 144,000$ of back pay awarded by the district court plus interest, and her lawyer received $\$ 247,500$. See Linda Greenhouse, Affirmative Action Settlement: The Overview, N.Y. TIMES, Nov. 22, 1997, at Al.

152 See Abby Goodnough, Financial Details Are Revealed in Affirmative Action Settlement, N.Y. TIMEs, Dec. 6, 1997, at Al [hereinafter Goodnough, Financial Details]; Abby Goodnough, Why Piscataway Decided to Avoid Spotlight, N.Y. TIMEs, Dec. 2, 1997, at B5 [hereinafter Goodnough, Avoid Spotlight].

153 See Goodnough, Avoid Spotlight, supra note 152, at B5. The Black Leadership Forum, a group of the leaders of a dozen major civil rights groups including the Urban League and the NAACP Legal Defense and Educational Fund, was the leadership of the coalition. See Greenhouse, supra note 151, at A1. 
Because the parties to the case had reached a settlement, the Supreme Court dismissed the case as moot $^{154}$ in accordance with the "case or controversy" clause of Article III. ${ }^{155}$

\section{b. The Likely Effect of the Piscataway Settlement on the Evolution of Affirmative Action Precedent}

Piscataway is an example of the importance of path dependence to the development of precedent. If Piscataway had not settled, it would likely have created an important affirmative action precedent. The Black Leadership Forum therefore viewed the Piscataway settlement as a major victory:

On Nightline, Kweisi Mfume, delighted that the case had been blocked from the Supreme Court, predicted that a bright new formula has been found to achieve further civil rights victories: "The real fact of the matter," Mfume said, "is that civil rights groups have learned the tactics of the extreme right wing, have adjusted to them, and have found a way to beat them at their own game. So we're not running. We're getting smarter."156

However, although Piscataway did settle, other cases will likely come through the pipeline to the Supreme Court. Why then did civil rights groups strive to settle Piscataway? Civil rights leaders apparently feared that the stark facts of Piscataway-two equally junior teachers, one black, one white-would make for more unfavorable law than other cases: ${ }^{157}$

154 See Piscataway Township Bd. of Educ. v. Taxman, 521 U.S. 1117 (1997). But cf. Honig v. Doe, 484 U.S. 305, 330 (1988) (Rehnquist, C.J., concurring) ("I ... would go still further in the direction of relaxing the test of mootness where the events giving rise to the claim of mootness have occurred after our decision to grant certiorari or to note probable jurisdiction.").

155 See supra note 26 and accompanying text.

156 Hentoff, supra note 107 , at 20.

157 See Roger Abrams, Diversity Defenders Await Post-Taxman Battles, N.J. L.J., Dec. 29, 1997, at 23 ("The Taxman case was a very poor vehicle to re-examine the constitutionality of race-conscious decision making. Why? Because, by stipulation, race was the only factor that distinguished the two candidates for purposes of deciding who should be laid off. That, of course, could never be true and is never true, except in a law school hypothetical, in a stipulated case such as this one or in the minds of advocates who pray for a return to the old days, when the old-white-boy network determined who would stay and who would go."); see also Barry Bearak, Rights Groups Ducked a Fight, Opponents Say, N.Y. Times, Nov. 22, 1997, at A1 (" 'There is an old adage that bad cases make for bad law, and this was one of the worst cases imaginable for defenders of affirmative action,' said Hugh B. Price, president of the National Urban League, which is part of the leadership forum. 'This case has such a narrow set of circumstances,' Mr. Price said, 'and the fear was that this case could spill over into 
African-Americans and other victims of race prejudice owe a deep debt of gratitude to the Piscataway School Board and their attorney, David Rubin, for settling the Piscataway affirmative action case. Had the case not been settled, we would have witnessed the effective end of affirmative action by summer's end.

The U.S. Supreme Court has chiseled away at the constitutional foundation for affirmative action efforts since the 1980s. In light of this political reality, this court might well have silenced all affirmative action programs with a decision in this case. crisis. ${ }^{158}$

By settling the case, the Piscataway School Board averted this

By settling Piscataway, civil rights leaders hoped that the case from which the Supreme Court makes law will have facts more favorable to their cause. ${ }^{159}$ In addition, it might be a while before another "reverse discrimination" case is appealed to the Supreme Court. ${ }^{160}$ Settlement succeeded in altering not only which case would be heard by the Court but also the timing of when such a case would be heard and perhaps the order of such cases. ${ }^{161}$ Depending on the composition of the Court when the next case is heard, this strategy may alter the substantive result in the case. 162

Under the mootness jurisprudence discussed above, the Supreme Court had no choice but to dismiss Piscataway once Ms. Taxman and

other factual situations. The Court has ruled that race can be used as one factor in promoting diversity and you wouldn't want a wide ruling that changes that.' "); John Kolbe, Affirmative Action Backers Ty to Buy Their Own Justice, ArIz. Republic, Nov. 30, 1997, at H5 ("Kweisi Mfume, director of the National Association for the Advancement of Colored People; defended the settlement on grounds that the Piscataway suit, because of its special facts, was 'inappropriate' to use as a vehicle for judging affirmative action.").

158 Winkfield F. Twyman, Doing the Right Thing: One Lawyer's Sacrifice, SAN Drego Union-Trib., Nov. 27, 1997, at B9.

159 See Abrams, supra note 157, at 23 ("Recently, the Center for Individual Rights, the right-wing crowd of counter-revolutionary lawyers in Washington which has spearheaded this attack, brought suit against the University of Michigan and then separately against the University of Michigan Law School. Another suit against the University of Washington is in its early stages. These cases, when they are tried, will place the case for affirmative action in a more realistic framework than Taxman.").

160 See id. ("Although conservative groups had salivated at the prospect of winning big in Taxman, they will have to wait for years to get another chance to kill off racial equity. Eventually, the Supreme Court will hear the cases that will determine the future of our commitment to diversity.").

161 See supra notes 106-23 and accompanying text.

162 Cf. Stearns, supra note 82 , at 1315. 
the school board entered into a settlement. ${ }^{163}$ The fact that third parties had provided funds toward the settlement was simply irrelevant to the determination that Piscataway was no longer justiciable. Ironically, in the Piscataway context, justiciability doctrine facilitated interest-group path-manipulation. Although most cases settle, ${ }^{\mathbf{1 6 4}}$ and although cases have settled even after the Supreme Court has granted certiorari, ${ }^{165}$ the role of civil rights groups in the settlement caused an outcry among many people about the inappropriateness of third-party engineering of the evolution of the law. ${ }^{166}$ The merits of this outcry are considered in Part III.B below.

\section{B. Article I Courts and Precedent Manipulation}

Unlike Article III courts, Article I courts are created by Congress under its enumerated powers ${ }^{167}$ coupled with its authority to make laws "necessary and proper for carrying into Execution the foregoing Powers, and all other Powers vested by this Constitution in the Government of the United States, or in any Department or Officer thereof."168 These courts generally are specialized courts such as the Tax Court; ${ }^{169}$ lie outside of the fifty states, such as the Territorial

163 Nevertheless, Chief Justice Rehnquist has argued that once the Supreme Court has granted certiorari or noted probable jurisdiction, mootness doctrine should not necessarily prohibit the Court from hearing the case if subsequent events have rendered it moot. See, e.g., Honig v. Doe, 484 U.S. 305, 329-32 (1988) (Rehnquist, C.J., concurring).

164 See supra note 1.

165 See, e.g., U.S. Bancorp Mortgage Co. v. Bonner Mall Partnership, 513 U.S. 18, 20 (1994) ("After we granted the petition [for certiorari] ... and received briefing on the merits, Bancorp and Bonner stipulated to a consensual plan of reorganization, which received the approval of the Bankruptcy Court. The parties agreed that confirmation of the plan constituted a settlement that mooted the case.") (citation omitted).

166 See Bearak, supra note 157, at AI ("They were ready to fight and the other guy backed out, disappointed affirmative action opponents said yesterday, complaining that the $\$ 433,500$ settlement in the Piscataway, N.J. case amounted to hush money paid by frightened civil rights groups."); Sullivan, supra note 149, at C1 ("When civilrights groups engineered a sudden settlement last month of a major affirmative action case before the Supreme Court, mooting the case and preventing the court from reaching any ruling, many professed to be shocked, shocked, that the court's docket could be so manipulated.").

167 The Tax Court is established under Congress' power to "lay and collect taxes." U.S. ConsT. art. I, § 8, cl. 1; see also I.R.C. $\$ 7441$ (1999).

168 U.S. Consr. art. I, § 8, cl. 18; see also Martin H. Redish, Legislative Courts, Administrative Agencies, and the Northern Pipeline Decision, 1983 Duke L.J. 197, 198.

169 The Tax Court was established by Int. Rev. Code of 1954, $\$ 7441$, as amended by Pub. L. No. 91-172, § 951, 83 Stat. 730 (1969). 
courts; 170 and/or are involved in adjudicating "public rights," 171 that is, cases in which the United States is a proper party. ${ }^{172}$ Functionally, Article I courts are subject to more limitations than Article III courts because of the greater independence of the Article III judiciary. ${ }^{173}$ However, Article I courts are not constrained by the "case or controversy" clause of Article III of the Constitution. Otherwise, Article I courts and Article III courts evidence few differences. For example, Tax Court and district court decisions are both reviewed by the courts of appeals, Article III courts. ${ }^{174}$ Both the Tax Court and the district courts also follow applicable court of appeals precedent. ${ }^{175}$ As in Article III courts, the Federal Rules of Evidence apply in Tax Court. ${ }^{176}$

170 See Barnard v. Thorstenn, 489 U.S. 546 (1989). The territorial courts are those in Guam, the Virgin Islands, the Northern Mariana Islands, and American Samoa. See 56 Charles Alan Wright, Law of Federal Courts $\$ 11$ (5th ed. 1994).

171 See Northern Pipeline Constr. Co. v. Marathon Pipe Line Co., 458 U.S. 50, 67 n.18 (1982) ("Congress' power to create legislative courts to adjudicate public rights carries with it the lesser power to create administrative agencies for the same purpose, and to provide for review of those agency decisions in Art. III courts."). But see id. at 113 (White, J., dissenting) ("[T]here is no difference in principle between the work that Congress may assign to an Art. I court and that which the Constitution assigns to Art. III courts."); see also Murray's Lessee v. Hoboken Land \& Improvement Co., 18 U.S. (1 How.) 272, 284 (1856) ("At the same time there are matters, involving public rights, which may be presented in such form that the judicial power is capable of acting on them, and which are susceptible of judicial determination, but which congress may or may not bring within the cognizance of the courts of the United States, as it may deem proper.").

172 See Northern Pipeline, 458 U.S. at 70.

173 See Herbert C. Shelley et al., The Standard of Review Applied by the United States Court of Appeals for the Federal Circuit in International Trade and Customs Cases, 45 AM. U. L. REv. 1749, 1826 n.427 (1996) ("Article III courts are structurally more independent than their legislative counterparts (Article I courts) .... This is due to: (1) the life tenure afforded Article III judges; (2) Article III courts not being connected to any particular government agency; (3) Article III courts having their jurisdiction largely defined by the Constitution; and (4) the limitation on reductions in salaries of active Article III judges. Due to this greater degree of independence, it is generally assumed that the decisions of an Article III court are less likely to be affected by political agendas or the majority position of the populace on a given issue or at a particular time.").

174 See I.R.C. § 7482 (West Supp. 1999) (dealing with Tax Court); 28 U.S.C. § 1291 (1994) (dealing with district courts).

175 See Golsen v. Commissioner, 54 T.C. 742 (1970). However, the Tax Court's jurisdiction is limited by statute, so it has no equity jurisdiction. Article I courts such as the Tax Court also do not have jury trials.

176 See I.R.C. $\$ 7453$ (West Supp. 1999). 


\section{The Smith Story}

Smith v. Commissioner, ${ }^{177}$ a Tax Court case, reveals the different effect third-party manipulation of settlement can have in an Article I court from the effect in an Article III court. In Smith, Mr. and Mrs. Smith and Mr. and Mrs. Jacobson had been partners in a real estate venture that had generated large gains. ${ }^{178}$ In order to lower the tax liability on these gains, they had purchased silver "straddles" from Merrill, Lynch, Pierce, Fenner \& Smith (Merrill Lynch). ${ }^{179}$ The straddles were designed to create losses in silver futures ${ }^{180}$ in one year that would be offset by gains in the following year, allowing postponement of short-term capital gains from one tax year until the next, and depending on the price movement of silver, the underlying commodity, possible conversion of short-term capital gain into tax-advantaged long-term capital gain. ${ }^{181}$ Merrill Lynch only offered these straddles to clients in a fifty percent or higher tax bracket, and received a commission of ten percent of the taxes saved. ${ }^{182}$ Silver straddles were used because silver was a highly stable commodity, minimizing the risk of economic loss. ${ }^{183}$

The Internal Revenue Service (IRS) audited the couples and disallowed the deductions for the silver futures on which the couples had realized losses. ${ }^{184}$ The IRS had ruled in 1977 that silver straddle losses were nondeductible because there was no real risk of economic loss. ${ }^{185}$ At the time of Smith, the IRS had several thousand straddle

17778 T.C. 350 (1982).

178 See id. at 351.

179 See November 3, 1980 Tax Court Transcript at 58, 60-61, Smith, 78 T.C. at 350 (No. 12709-77) [hereinafter Smith Transcript].

180 "A futures contract is an agreement to buy or sell a commodity at some future date for a specified price." Jerry Knight, IRS Seeks to Halt "Silver Butterfly" Tax WriteOffs, Wash. Post, Apr. 6, 1981, at A1.

181 See Smith, 78 T.C. at 352. A small economic loss could occur. See id. at 352-53; see also Samuel C. Thompson, Jr., An Examination of the Effect of Recent Legislation on Commodity Tax Straddles, 2 VA. TAx REv. 165, 167 n.12 (1983) ("Because the legs of the straddle tend to move in opposite directions with any increasing loss on one leg being balanced by increasing profit on the other, the risk of the straddle transaction is limited to the spread, or difference in value, of the legs of the straddle when the taxpayer first enters into the transaction.").

182 See Smith Transcript at 22, 24; Jerry Knight, Regan's Firm Pushed Tax Avoidance Deals, WASH. Post, Dec. 16, 1980, at A1.

183 See Jerry Knight, Silver Butterfly "The Best Little Tax Dodge in America," Wash. Post, Dec. 21, 1980, at G1.

184 The IRS had sent the taxpayers a notice of deficiency dated October 7, 1977. See Memorandum of Law in Support of Motion at 6.

185 See Rev. Rul. 77-185, 1977-1 C.B. 48. This ruling involved a simple straddle, however, not a "butterfly" straddle such as the one involved in Smith. 
loss cases under consideration. ${ }^{186}$ Smith was the Tax Court's first case on the issue, however. ${ }^{187}$

As a result of the IRS's disallowance of their tax losses, the Smiths and the Jacobsons sued Merrill Lynch in California state court. ${ }^{188}$ Merrill Lynch, apparently fearing an unfavorable Tax Court precedent that would eliminate its profitable straddle business, ${ }^{189}$ settled the case with the couples ${ }^{190}$ for twice the amount of the federal tax liability in dispute. ${ }^{191}$ Accordingly, approximately a week before trial was scheduled to begin, ${ }^{192}$ the couples offered in Tax Court to concede the tax liability. ${ }^{193}$ The IRS refused to accept the offer. ${ }^{194}$ Judge Nims rejected the couples' concession, apparently concerned that Merrill Lynch was interfering in the case to prevent a precedent. ${ }^{195}$ Article I of the Constitution did not preclude the Tax Court from hearing the case. Thus, trial went forward as scheduled, despite the taxpayers' ${ }^{196}$ stated desire to concede the case. ${ }^{197}$ After trial, the court

186 See W. John Moore, Wounded IRS Takes Aim on Tax Straddle Plans, Legal Times, Apr. 12, 1982, at 1 (quoting IRS Reply Brief).

187 See Smith, 78 T.C. at 362.

188 See Smith Transcript at 40,59; see also Moore, supra note 188, at 1.

189 See Smith Transcript at 40,59 . The business apparently had earned millions of dollars in commissions. See id.

190 See Jerry Knight, Court Won't Let 2 Couples Drop Suit Against IRS, Wash. Post, Nov. 4, 1980, at D7.

191 See id. The excess amount over the couples' $\$ 57,000$ tax deficiency was probably to cover the interest on the deficiency, their California state tax liability and interest. See I.R.C. $\$ \S 6601,6621$ (West Supp. 1999) (regulating/governing interest on underpayments of tax); Smith Transcript at 29 (stating that $\$ 114,000$ would probably cover their deficiencies plus interest; rate of interest was $18 \%$ ). However, the IRS argued that the $\$ 114,000$ exceeded the aggregate of those amounts. See id. at 12; Memorandum in Opposition to Petitioners' Notice of Concession at 3 \& n.I.

192 The concession was offered on November 3. See Smith Transcript at 1. The trial had been scheduled for November 10,12, and 13, and December 16 and 17. See id. at 44.

193 See id. at 2, 66.

194 See id. at 63-67; Memorandum of Law in Support of Motion at I. It is unclear whether the taxpayers' settlement of the suit against Merrill Lynch was contingent on their full concession offer, and whether they received the $\$ 114,000$ despite Judge Nims' refusal to dismiss the case. Smith is paradigmatic of the effect of a repeat player on one side of the litigation. The IRS would not accept the taxpayers' full concession because it valued the precedent more than the cost of litigating the case.

195 See Smith Transcript at 48; infra note 212 and accompanying text; $c f$. Mootness, supra note 89, at 1692 (stating that where the mootness doctrine "perpetually frustrate[s] 'the vital importance of keeping open avenues of judicial review," the need for review overrides the policies of mootness, and "the Court should not refuse review on the basis of mootness") (quoting Sibron v. New York, 392 U.S. 40, 52 (1968)).

196 A taxpayer is "any person subject to any internal revenue tax." I.R.C. $\S 7701$ (a) (14) (West Supp. 1999). In the context of Smith, the taxpayers were the two 
ruled in favor of the IRS on the underlying issue on the ground that the taxpayers had not entered into the straddles for profit. ${ }^{198}$

\section{The Effects of Smith}

The Tax Court, like other courts, ${ }^{199}$ is pro-settlement. ${ }^{200}$ In fact, Tax Court judges often encourage settlement. ${ }^{201}$ In addition, the Tax Court has held that, as a matter of policy, it is subject to "case or controversy" restrictions, ${ }^{202}$ particularly because its decisions are review-

couples, the Smiths and the Jacobsons, litigating their tax dispute against the IRS. See Smith, 78 T.G. at 350.

197 See Smith, 78 T.C. at 350; Smith Transcript at 66-67.

198 See Smith, 78 T.C. at 350. Ironically, the IRS's victory was bittersweet. The court's rejection of the IRS's argument that the silver straddles had no economic substance preserved the possibility that other taxpayers with a bona fide, if illfounded, profit motive could deduct their losses. See IRS to Pursue Past Straddle Abuses, as Industry Circles Wagons, SEc. WK., Sept. 6, 1982, at 6 ("IRS also lost a major straddle test in tax court last spring in the Smith-Jacobson case. In that decision, attorneys point out, the service may have 'won the battle but lost the war.' Straddling by Smith and Jacobson was deemed to be tax-motivated, but the court refused to go along with the IRS's belief in the general invalidity of straddling under pre-1981 law."). The IRS moved for reconsideration of the case, in search of a broader, sweeping precedent. See Moore, supra note 188 , at 1 . The motion was denied. See id. The IRS continued to litigate the issue, see Landreth v. Commissioner, 859 F.2d 643, 644 (9th Cir. 1988) (citing cases), prompting Congress to act, see id.; H.R. CoNF. REP. No. 98-861, at 916-17 (1984), reprinted in 1984 U.S.C.C.A.N. 697, 1445, 1604-05. In 1984, Congress enacted a provision governing the tax treatment of pre-1981 commodity straddles. See Deficit Reduction Act of 1984, Pub. L. No. 98-369, § 108(a), 98 Stat. 494, 630 (stating that losses from the disposition of one or more positions in a commodity straddle entered into before June 23, 1981 are deductible if the loss was incurred in a transaction entered into for profit). The provision eclipsed Smith in that it provided a statutory rule. See Miller v. Commissioner, 84 T.C. 827, 834, 842 (1985), rev'd, 836 F.2d 1274 (10th Cir. 1988).

199 See infra notes 236-38 and accompanying text.

200 See, e.g., Barrett v. Commissioner, 96 T.C. 713, 720 (1991) ("The policy of the law is to foster the peaceful settlement of disputes without litigation."); Tate \& Lyle, Inc. v. Commissioner, 69 T.C.M. (RIA) 661 (1996). The Tax Court generally will not retain jurisdiction after the parties have agreed to a settlement. See LTV Corp. v. Commissioner, 64 T.C. 589 (1975).

201 See Lederman, supra note 48; Meade Witaker, Some Thoughts on Current Tax Practice, 7 VA. TAX REv. 421, 435 (1988) ("Most litigants before the Tax Court are aware that this court encourages settlement of valuation cases, because a settlement by the parties usually results in a better decision at a much earlier date.").

202 As a practical matter, unripe cases cannot be litigated in Tax Court because a notice of deficiency from the IRS and timely responsive petition are jurisdictional requirements. See I.R.C. \$§ 6214, 6512(b) (West Supp. 1999); Leandra Lederman, Civilizing Tax Procedure: Applying General Federal Leaming to Statutory Notices of Deficiency, 30 U.C. DAvrs L. REv. 183 (1996). Similarly, these requirements mean that a taxpayer 
able by the courts of appeals. ${ }^{203}$ In an Article III court, the full concession by the Smiths and the Jacobsons would have rendered the case moot. ${ }^{204}$ Yet, Judge Nims never mentioned the possibility that the case was moot, ${ }^{205}$ nor did the parties' Memoranda of Law. ${ }^{206}$

must have standing in order to petition the Tax Court. Payment of the deficiency prior to issuance of a notice of deficiency has been held to eliminate Tax Court jurisdiction on the theory that the notice of deficiency is not valid, even if that is contrary to the parties' intent. See, e.g., Standard Oil Co. v. McMahon, 244 F.2d 11, 13 (2d Cir. 1957) ("[I]f prior payment has extinguished the 'deficiency,' there is no jurisdiction in the Tax Court even though this be contrary to the intention of the parties."); Bendheim v. Commissioner, 214 F.2d 26, 28 (2d Cir. 1954); McConkey v. Commissioner, 199 F.2d 892, 893-94 (4th Cir. 1952); Anderson v. Commissioner, 11 T.C. 841, 842 (1948). In addition, settled cases are generally entered by the court as stipulated decisions which means that the court does not generally require parties to continue litigating moot cases.

203 See Anthony v. Commissioner, 66 T.C. 367 (1976). Tax Court cases are somewhat less path-dependent than cases in other courts. If a Court of Appeals case is squarely on point in the Court of Appeals to which appeal would lie, which is the circuit in which the taxpayer resided at the time he petitioned the court, then that precedent controls the Tax Court outcome. See Golsen v. Commissioner, 54 T.C. 742 (1970), aff'd on other grounds, 445 F.2d 985 (10th Cir. 1971). In cases where there is no Court of Appeals precedent on point, the Tax Court develops its own rule, making those cases path-dependent because individual judges decide each case. But of. Caminker, supra note 78, at 824 n.28 ("The Tax Court most starkly illustrates the duty [to obey hierarchical precedent's] path-dependent nature. Tax Court decisions are reviewable by Article III courts of appeals; which court will review a decision depends on factors such as where the disputed tax return was filed. When the Tax Court can identify in advance the court of appeals with revisory jurisdiction over a particular case, the Tax Court adheres to that court's precedents. Hence the Tax Court may decide similar cases differently because they are appealable to different federal circuits.").

204 See supra note 93 and accompanying text.

205 If the IRS had accepted the taxpayers' concession and subsequently requested the Tax Court to decide the issue anyway, the Tax Court's willingness to do so would depend on whether the parties had actually entered into a settlement agreement, and whether that agreement had been entered by the court as a stipulated decision. If a party backs out after accepting a concession, but prior to executing a decision document, the Tax Court treats that somewhat similarly to a unilateral full concession offer rejected by the other party, but balances that party's prior acceptance of the concession. See, e.g., Greenlee v. Commissioner, 54 T.C.M. (P-H) 957, 959 (1985) (“In McGowan the substantive issue before this Court affected many taxpayers and the public interest required its resolution. This case is distinguishable in that only the petitioner and Greenlee, Inc. will be affected by our decision."); Smith v. Commissioner, 34 T.C.M. (P-H) 1252 (1965) (accepting IRS's concession and issuing an opinion reciting the facts of the case and acceptance of the concession). By contrast, if the parties have actually entered into a settlement agreement and one party subsequently seeks to be relieved of that agreement, the Tax Court takes a stricter stance.

The party seeking modification ... must show that the failure to allow the modification might prejudice him .... Discretion should be exercised to 
Despite its pro-settlement policy and despite its general adherence to justiciability concepts, on two prior occasions the Tax Court had refused to dismiss cases in which one party tried to fully concede. ${ }^{207}$ In both of those prior cases, it was the IRS that sought to

allow modification where no substantial injury will be occasioned to the opposing party; refusal to allow modification might result in injustice to the moving party; and the inconvenience to the Court is slight.

Adams v. Commissioner, 85 T.C. 359, 375 (1985) (citations omitted). However, Judge Parr recently expressed her view that the Tax Court has a right to reject even a bilateral settlement agreement.

I write separately . . . to emphasize that nothing in the majority opinion should be understood to limit the sound discretion of the Court to reject an agreement between the parties, where good cause is shown and the interests of justice require it.

It is easy to imagine a situation, not here present, where an agreement between the parties may not be in the interests of justice. For instance, agreements that would abuse the process of this Court, or that would usurp the Court's control over its calendar, or that would be contrary to sound public policy should not be enforced.

Dorchester Indus., Inc. v. Commissioner, 108 T.C. 320, 343 (1997) (Parr, J., concurring). If the motion is on the eve of trial, and a trial date has been canceled in reliance on the parties' purported settlement agreement,

the moving party ha[s] to satisfy standards akin to those applicable in vacating a judgment entered into by consent: "In such cases, the parties are held to their agreement without regard to whether the judgment is correct on the merits." Absent a showing of lack of formal consent, fraud, mistake, or some similar ground, a judgment entered by consent will be upheld.

$I d$. at 335 (reviewed by the full court) (quoting Stamm Int'l Corp. v. Commissioner, 90 T.C. 315,322 (1988)); see also Mearkle v. Commissioner, 87 T.C. 527, 528 (1986), rev'd and remanded, 838 F.2d 880 (6th Cir. 1988).

Thus, if a stipulated decision had been entered, the Tax Court would be unlikely to override the parties' agreement ending the Tax Court's involvement in the case unless one party subsequently sought relief from that decision. In that situation, Merrill Lynch would have been as successful in Smith as the Black Leadership Forum was in Piscataway, discussed above, demonstrating that the agreement of the parties to the case to a settlement is key, at least in Tax Court. See supra notes 132-78 and accompanying text. Apparently, the Tax Court's position is that the parties' agreement is of foremost importance. If the parties have agreed to a bilateral settlement and one party later changes its mind, the court will apply a very deferential level of review because agreement did exist at one time. On the other hand, if the objecting party never accepted a full concession proposal, the Tax Court views the parties as still litigating and therefore subject to its decision-making power.

206 See Smith Transcript; Memorandum of Law in Support of Motion; Memorandum in Opposition to Petitioners' Notice of Concession.

207 See, e.g., McGowan v. Commissioner, 67 T.C. 599 (1976) (stating that in the interest of justice, Tax Court could retain jurisdiction despite the willingness of the IRS to concede the entire case); Hisacres New Thought Ctr. v. Commissioner, 32 T.C.M. (P-H) 726 (1963) (holding for taxpayer in the underlying case despite tax- 
concede the case and the taxpayer who refused the concession. ${ }^{208}$ Those cases were motivated by IRS fear of an unfavorable precedent, and they differ conceptually from Smith in that the Tax Court's refusal to dismiss cases where the IRS concedes but the taxpayer pushes for a court decision may be motivated by prevention of IRS "manipulation" of the court system. The IRS, unlike most taxpayers, is a repeat player in Tax Court. In fact, the IRS is a party to every Tax Court deficiency case. ${ }^{209}$ Absent Tax Court action, the IRS theoretically could pursue many taxpayers, then concede the ones in which a taxpayer with a strong case petitions the Tax Court, counting on its ability to pursue cases with more favorable facts later on. Smith raises no such possibility because the taxpayers, not the IRS, sought to concede the case. ${ }^{210}$ There are other cases in which the IRS sought entry of a decision and the taxpayer resisted, ${ }^{211}$ but Smith is the only known case in which the Tax Court actually sided with the IRS in such a situation, refusing to enter a decision. ${ }^{212}$

Regardless of whether the Tax Court considered the possibility that the case should be dismissed as moot, it is clear that Judge Nims's unusual step in deciding a case despite a full concession by the taxpayers was influenced by its perception that a non-party was interfering in

payer opposition to IRS motions to completely concede all issues); Smith Transcript at 2.

208 See McGowan, 67 T.C. at 599 (1976); Hisacres, 32 T.C.M. (P-H) at 726. Neither case has been cited very often. McGowan was cited in one case for its substantive outcome, and the court ruled consistently with it. See Trujillo v. Commissioner, 68 T.C. 670,672 (1977). Hisacres has not been cited for its substantive position.

209 See Lederman, supra note 48 , at 342.

210 Smith was therefore a case of first impression on this procedural issue. See Smith Transcript at 63.

211 See, e.g., LTV Corp. v. Commissioner, 64 T.C. 589 (1975). The reason why, absent third-party intervention such as in Smith, a taxpayer might reject a "full concession" offered by the IRS in a Tax Court case is because of the nature of tax litigation. Taxes are computed annually, and each year is a separate cause of action, so the Tax Court's jurisdiction is over a particular tax year or years, specifically, those for which the taxpayer received a notice of deficiency and timely petitioned the court. See Commissioner v. Sunnen, 333 U.S. 591 (1948). A "full concession" by the IRS might leave the taxpayer open to subsequent disputes with the IRS in other years if the issue is a recurring one, so the taxpayer might prefer to reject the concession and litigate in order to obtain a precedent. Theoretically, the settlement amount could be adjusted to compensate the taxpayer for this inconvenience, but the IRS is not in a position to "bribe" a taxpayer to accept a settlement, or even to promise to forego audit of other years. But cf. Doctors Hill \& Thomas Co. v. United States, 392 F.2d 204, 204-05 (6th Cir. 1968) (describing a situation in which the IRS offered taxpayer company not only the taxes claimed as a refund, but all the taxes the company had paid for that year).

212 See Smith Transcript at 63. 
the case to prevent a precedent. ${ }^{213}$ However, Merrill Lynch did nothing wrong in pursuing its own interest. In fact, Merrill Lynch became involved because the Smith taxpayers sued Merrill Lynch in state court and because the IRS subpoenaed some of its documents. ${ }^{214}$ There is nothing illegal in Merrill Lynch's settlement of the California state court case in return for the taxpayers' agreement to concede the Tax Court case. In a sense, Merrill Lynch was merely indemnifying the taxpayers for their tax liability, plus an additional amount, ${ }^{215}$ perhaps to cover their costs of litigating the dispute with the IRS.

Because of Judge Nims's apparent aversion to Merrill Lynch's attempt to eliminate a precedent, he applied the standards developed in cases of IRS full concession, examining whether the interests of justice would be served by entering a decision in accordance with the concession, or instead by proceeding to trial. In those cases, the court considered both whether the issues would likely be recurrent for the particular taxpayer ${ }^{216}$ and the potential precedential value of the opinion. ${ }^{217}$ Where an issue will be recurrent for the particular taxpayer but will have little precedential value for other taxpayers, the Tax Court is likely to simply accept a concession. ${ }^{218}$

Thus, the Tax Court's primary consideration was the extent to which other taxpayers would be affected by the precedent resulting from its decision. ${ }^{219}$ The fact that, in Article III courts, third-party benefits such as precedential value are irrelevant to the issue of whether a case is moot ${ }^{220}$ did not enter the Tax Court's calculus in Smith. In addition, Judge Nims did not distinguish between, on the one hand, the IRS' ability, as a party to every Tax Court case, to ma-

213 Judge Nims seemed concerned about taxpayer "manipulation" of the system by conceding, at the "eleventh hour," a case that was ready to go to trial. See Smith Transcript at 48.

214 See Smith Transcript at 57-59.

215 See supra note 191 and accompanying text.

216 See, e.g., Hisacres New Thought Ctr. v. Commissioner, 32 T.C.M. (P-H) 726 (1963) (finding in favor of taxpayer who opposed IRS motions to concede all issues on the ground that the issues were recurrent).

217 See McGowan v. Commissioner, 67 T.C. 599, 607-08 (rejecting IRS's concession where opinion would likely have precedential value to a large number of taxpayers).

218 See Cape Fox Corp. v. Commissioner, 63 T.C.M. (CGH) 3184 (1992); cf. LTV Corp. v. Commissioner, 64 T.C. 589 (1975).

219 Oddly enough, despite its interest in precedent, the Tax Court has a history of selective disclosure of its opinions. Its opinions in small tax cases were not publicly available for quite a while, in spite of the Code's requirements that Tax Court opinions be public documents. See Leandra Lederman, Tax Court S Cases: Does the 'S' Stand for Secret?, 79 TAx Notes 257 (1998).

220 See supra notes $26-27$ and accompanying text. 
nipulate the court's docket through deciding which cases to pursue and which to concede at which point, and on the other hand, the taxpayer's responsive position in litigating a single Tax Court case. ${ }^{221}$ Judge Nims's decision, which ignored justiciability principles, required parties who were no longer adverse to continue litigating. ${ }^{222}$

\section{Balancing Settlement and Precedent}

Settlement and precedent conflict because the former necessarily precludes the latter. ${ }^{223}$ This Part explores the appropriate balance between private and public interests, in order to arrive at an appropriate policy that balances both the need for settlement and the need for precedent.

As Parts I and II of the article observed, litigants generally have an economic incentive to settle. ${ }^{224}$ The possible precedential value of a decision in their case matters to them only insofar as they are repeat players who may themselves be affected by that precedent.225 Thus, the private interest is generally settlement.

The public's interest is more complicated. The public benefits from precedent. ${ }^{226}$ Thus, in general, the public has a stronger interest in precedent than do private litigants. However, the public also benefits from lowered public costs of litigation. This in turn implies a need for settlement because, if the volume of trials increases, at some point there may be a need to increase the number of judges or courts-which are funded by public money. The public therefore has some interest in a certain volume of settlements, but much less of an incentive that any particular case settle than do the individual litigants.

221 Although the taxpayer is the one who actually brings Tax Court litigation, functionally the taxpayer is the defendant. See Lederman, supra note 221.

222 The parties did disagree on whether the court should decide the case, but that is not the kind of adversariness that leads to clear, partisan presentation of the underlying tax issues. They were no longer adversaries on those issues.

223 See Fiss, supra note 8, at 1085 ("In our political system, courts are reactive institutions. They do not search out interpretive occasions, but instead wait for others to bring matters to their attention. They also rely for the most part on others to investigate and present the law and facts. A settlement will thereby deprive a court of the occasion, and perhaps even the ability, to render an interpretation.")

224 See supra notes 28-32 and accompanying text.

225 See supra note 32 and accompanying text.

226 See Izumi Seimitsu Kogyo Kabushibi Kaishi v. U.S. Phillips Corp., 510 U.S. 27, 41 (Stevens, J., dissenting) ("The public interest in preserving the work product of the judicial system should always at least be weighed in the balance before such a motion [vacatur] is granted."); see also supra text accompanying note 45 . 


\section{A. Why Do We Encourage Settlement?}

Most courts and commentators express support for the settlement of lawsuits. ${ }^{227}$ In fact, despite the high percentage of settlements, ${ }^{228}$ and the fact that economic models predict such a high settlement percentage even without third-party intervention, ${ }^{229}$ legal rules favor settlement. ${ }^{230}$ Federal policy seems to favor settlement and disfavor litigation, as reflected in the Civil Justice Reform Act, ${ }^{231}$ Federal Rule of Civil Procedure 68, ${ }^{232}$ Federal Rule of Evidence 408's exclusion from evidence of settlements and settlement offers, ${ }^{233}$ and statutory support for private contractual agreements to arbitrate rather than litigate. ${ }^{234}$ Although settlement is generally a private matter, public processes are often used to encourage settlement. ${ }^{235}$ In fact, most courts encourage settlement. ${ }^{236}$ Some courts have "settle-

\section{See infra notes $235-38$ and accompanying text.}

228 See supra note 1.

229 See supra notes 50-64 and accompanying text.

230 See Cordray, supra note 20, at 36 ("Settlement is favored in the law for a variety of reasons. From a practical standpoint, settlements significantly ease the burden on courts. When parties resolve their dispute through settlement rather than full litigation, the growing pressure on court dockets is relieved. Settlement thus enables courts to conserve scarce judicial resources and to reduce their considerable backlog. Settlement is, as a result, "indispensable to judicial administration." ") (quoting Janneh v. GAF Corp., 887 F.2d 433, 435 (2d Cir. 1989)); see also Carrie Menkel-Meadow, Whose Dispute Is It Anyway?: A Philosophical and Democratic Defense of Settlement (In Some Cases), 83 GEO. L.J. 2663, 2665 (1995) ("While court administrators, judges, and some lawyers suggest that we must continue to mine the advantages of settlement for caseload reduction, or equity among claimants, especially in mass torts or class action settings, many legal scholars continue to express concern with the use of settlement as a device for resolving our legal disputes.") (citations omitted).

23128 U.S.C. $\$ \$ 471-82$ (1994). It may encourage settlement. See MenkelMeadow, supra note 232, at 2665.

232 See Delta Air Lines, Inc. v. August, 450 U.S. 346, 352 (1981) ("The purpose of Rule 68 is to encourage the settlement of litigation.").

233 See Anne-Therese Bechamps, Sealed Out-of-Court Settlements: When Does the Public Have a Right to Know?, 66 NOTRE DAME L. Rev. 117, 129 (1990) ("Unquestionably the interest in encouraging settlements is important. The fact that the Federal Rules of Evidence exclude settlements and offers of settlement from the realm of admissible evidence is indicative of this strong public policy.").

234 See 9 U.S.C. $\$ \S 1-14$ (1994) (regulating maritime transactions); see also 5 U.S.C. $\$ 581$ (1996 \& Supp. 1999) (promoting alternative dispute resolution).

235 See supra notes 229-32 and accompanying text.

236 See, e.g., In re Warner Communications Sec. Litig., 618 F. Supp. 735, 740 (S.D.N.Y. 1985), affd, 798 F.2d 35 (2d Cir. 1986) (starting from "the familiar axiom that a bad settlement is almost always better than a good trial."); Henry E. Klingeman, Note, Settlement Pending Appeal: An Argument for Vacatur, 58 FordHAM L. Rev. 233, 233 n.1 (1989) ("District judges can encourage and participate in settlement negotiations 
ment weeks" or court-annexed arbitration, ${ }^{237}$ and individual judges use a variety of techniques to encourage settlement. ${ }^{238}$

The fact that public processes are used to encourage settlement is initially surprising because precedent has public value, ${ }^{239}$ and settlement is inconsistent with the possibility of a court decision that will serve as precedent. ${ }^{240}$ Most cases would settle even without judicial

through conferences. .. . The circuit court may also require a prehearing conference. ... Rule 33 provides in pertinent part that ' $[t]$ he court may direct the attorneys for the parties to appear before the court or a judge thereof for a prehearing conference to consider the simplification of the issues and such other matters as may aid in the disposition of the proceeding by the court . . . The Second Circuit Court of Appeals employs staff counsel who conduct pre-argument settlement conferences.") (citations omitted) (quoting FED. R. APP. P. 33); cf. In re Memorial Hosp., 862 F.2d 1299, 1302 (7th Gir. 1988) ("It is hard to be against settlement."); Galanter \& Cahill, supra note 21, at 1368 ("In addition to settlement promotion by trial judges, there are many settlement programs in other arenas, including at the appellate level. One success story reported significant increases in the settlement rates achieved by an appellate prehearing program.").

237 See generally Lisa Bernstein, Understanding the Limits of Court-Connected ADR: A Critique of Federal Court-Annexed Arbitration Programs, 141 U. PA. L. Rev. 2169 (1993).

238 See Galanter \& Cahill, supra note 21, at 1387 ("Courts have taken a full turn from settlement as accommodation within the structure of public rules to the dismantling of that structure as participants engage in the pursuit of settlement.").

239 See Erik Moller et al., RAND Corp., Private Dispute Resolution in the BANKING INDUSTRY 32 (1993) ("Cases that are resolved outside the traditional court system cannot be used to test current judicial interpretation. Courts not only resolve disputes but also establish, reinforce, and revise standards of conduct through their written disputes. No private $\mathrm{ADR}$ mechanism can serve this function. And if whole categories of cases are removed from public scrutiny, how appropriate changes in the common law and in statutory interpretation might be accomplished becomes a serious question."); see also Monica L. Warmbrod, Comment, Could an Attormey Face Disciplinary Actions or Even Legal Malpractice Liability for Failure to Inform Clients of Alternative Dispute Resolution?, 27 Cumb. L. REv. 791, 804 (1996) ("Even though the parties have come to an agreement, settlement of some cases may deprive the public interest of precedent and guidance for future conduct.") (citing H. Lee Sarokin, Justice Rushed Is Justice Ruined, 38 Rutgers L. REv. 431, 433 (1986)).

240 See supra note 3; Galanter \& Cahill, supra note 21, at 1386-87.

Settlements have so captivated many judges and policymakers that general effects are gladly sacrificed to secure settlements. Many courts are willing to destroy or alter precedent in an adjudicated case for the sake of a subsequent settlement by the parties. In doing so, courts find more compelling "the interests of private litigants in ending litigation through settlement" than the interests of the public in the finality and precedential value of judgments. ... What makes the processes of vacatur and stipulated reversals so interesting and disturbing is the willingness of courts to erase or manipulate precedent to promote a settlement.

Id. (quoting Jill E. Fisch, Reuriting History: The Propriety of Eradicating Prior Decisional Law Through Settlement and Vacatur, 76 CORNELI L. Rev. 589, 591 (1991)). 
intervention, ${ }^{241}$ so a logical question is why most courts and commentators favor encouraging settlement when it will necessarily eliminate potential precedent. The answer is partly a question of perspective. The dispute resolution model simply does not focus on precedent, but rather on a peaceful end to disputes. ${ }^{242}$ In other words, this viewpoint looks at the benefits but not the costs of settlement.

One economic reason for courts to encourage settlement is that parties do not internalize the costs to the public of continuing to litigate. ${ }^{243}$ In effect, taxpayers as a whole subsidize trials by bearing much of the costs of the public court system, ${ }^{244}$ perhaps distorting somewhat the parties' financial incentives to settle. ${ }^{245}$ Prodding by the court may help mitigate this distortion. On the other hand, taxpayer subsidy of trials is appropriate since precedents benefit the taxpaying public as well, ${ }^{246}$ which suggests that the taxpayer subsidy is not something parties should internalize.

Another possible reason to encourage settlement flows from the standard economic model of suit and settlement discussed in Part I. Under that model, parties factor in the costs of continuing to litigate in deciding whether to propose a settlement or to accept a settlement offered by the opposition. ${ }^{247}$ As discussed above, finding a settlement range depends on similar estimates of trial outcome by each side and the absence of strategic behavior. ${ }^{248}$ Attorneys may help somewhat in

241 See supra notes 50-64 and accompanying text.

242 See supra notes 20-23 and accompanying text.

243 Cf. Purcell, supra note 130, at 904 ("Disputes between private litigants have public significance for another reason: they are adjudicated in a public courtroom. The courtroom is staffed by judges, clerks, and bailiffs whose salaries are paid by the government. The costs of litigation are certainly burdensome, but the existence of government courts allows litigants to avoid paying an arbitrator to hear their case.") 244 See, e.g., J.S. KaKatik \& R.L. Ross, RAND CoRp., Costs of THE Civil Justice System: Court EXPEnditures for Various Types of Civil Cases (1983), cited in Brunet, 1985 Survey of Books Relating to the Law: IV. Politics, Government and Public Affairs: Measuring the Costs of Civil Justice, 83 Mich. L. REv. 916, 916 (1985) (stating that the federal cost of civil litigation was $\$ 2.2$ billion in fiscal year 1980); RICHARD POSNER, ECONOMIC ANALISIS OF LAW 493 (3d ed. 1986) (stating that the government provides judges' salaries and courthouses); Trubeck et al., supra note 30, at 78-79 ("[E]ven if both lawyers and clients gain from litigation, it does not follow that litigation is a costeffective process for society. The simple fact that taxpayers rather than litigants pay the cost of operating the courts shows why calculations of social and private costs must diverge.").

245 See William M. Landes \& Richard A. Posner, The Economics of Anticipatory Adjudication, 23 J. LEGAL STUd. 683, 689 (1994).

246 See supra note 45 and accompanying text.

247 See Lederman, supra note 48; Shavell, supra note 31.

248 See Shavell, supra note 31. 
each of these areas. ${ }^{249}$ Importantly, however, the judge can help the consistency of estimates by indicating his leanings on a particular issue. ${ }^{250}$ The judge can help eliminate strategic behavior by collecting settlement figures from each side and indicating whether there is an overlap. ${ }^{251}$ Judges have in fact employed both of these techniques, ${ }^{252}$ and characteristics of the judge deciding the case are significant predictors of the likelihood a case will settle. ${ }^{253}$

Although these are valid arguments in support of courts' tendencies to encourage settlement, these probably are not the primary reasons courts encourage settlement. Commentators who support settlement advance two main reasons: cost savings to the parties and alleviation of docket congestion. ${ }^{254}$ Yet, the parties internalize cost

249 See Lederman, supra note 48; Rachlinski, supra note 60, at 171, 172 (explaining that lawyers might frame settlement offers as "gains" rather than "losses," thus encouraging the client to settle, or they might do the opposite).

250 See Lederman, supra note 48.

251 See id.; cf. Galanter \& Cahill, supra note 21, at 1364 ("[B]ecause parties differ in their ability to secure shares of these savings [from avoiding litigation], settlement may add another layer of departure from equity. It is sometimes claimed that judicial intervention can offset such an effect, leading to more equitable distribution of the exchange surplus. But no systematic studies have examined this claim.") (footnote omitted).

252 See Carlton M. Smith, Innovative Settlement Techniques Can Reduce Litigation Costs, 78 J. TAX'N 76, 80 (1993) (“[In a Tax Court chambers conference, the] judge also may ask the parties if they would be interested in hearing the judge's tentative views on how he or she would rule in the case, assuming the parties presented the evidence they said they would present. The judge sometimes will give his or her views as a percentage, as in: ' $I$ think there is a $60 \%$ chance I will rule for the petitioner on this issue.' Giving views in this way often lends to quick settlements on the stated percentage basis."). Smith also notes, "A less common form of mediation that the judges employ in chambers conferences is to ask the parties if they would be willing to inform the judge of their settlement range without the other party being present. After the parties jointly discuss the case with the judge, the judge will speak to the parties separately (often with a law clerk present as a witness) to learn their settlement ranges. If the judge sees an overlap in those ranges, he may call the parties back into the room jointly and tell the parties that an overlap exists and even suggest a settlement number that both parties could live with." Id.; see also Judith Resnik, Managerial Judges, 96 HARv. L. REv. 374, 376 (1982) ("Many federal judges have departed from their ... relatively disinterested pose to adopt a more active, "managerial" stance. In growing numbers, judges are not only adjudicating the merits of issues presented to them by litigants, but also are meeting with parties in chambers to encourage settlement of disputes and to supervise case preparation. Both before and after the trial, judges are playing a critical role in shaping litigation and influencing results.").

253 See Lederman, supra note 48.

254 See, e.g., Jill E. Fisch, Rewriting History: The Propriety of Eradicating Prior Decisional Law Through Settlement and Vacatur, 76 CORNELI L. Rev. 589, 591 n.8 (1991) ("To the extent that settlement has the effect of reducing docket congestion and resolving 
savings from settlement, so they do not seem to need a push for that reason. Alleviating docket congestion apparently benefits litigants by speeding up court resolution of their cases. ${ }^{255}$ However, if litigants are pressured to settle, the costs of docket congestion may be shifted from future litigants (who would have to bear increased delay) to current litigants, ${ }^{256}$ who bear the increased pressure. ${ }^{257}$

In fact, the argument that settlement helps eliminate docket congestion does not hold true where the case at issue will provide precedent to help settle numerous other cases. For example, in Smith $v$. Commissioner, 258 the IRS made that very argument as to why the Tax Court should try the case rather than allow the two couples litigating against the IRS to concede the case. ${ }^{259}$ Tax Court Judge Nims accepted the IRS's argument, stating,

cases without further consumption of judicial resources, it obviously serves public as well as private interests.").

255 See Robert Scott Lewis, Recent Decision: U.S. Bancorp Mortgage Co. v. Bonner Mall Partnership: Settlement Conditioned on Vacatur?, 47 ALA. L. Rev. 883, 892 n.72 (1996) ("Much can be said for settlement; at a minimum it concludes one dispute and allows scarce judicial resources to be used in other pending litigation.") (citing Thomas D. Lambros, The Future of Alternative Dispute Resolution, 14 PEPP. L. REv. 801 (1987)).

256 Cf. In re Memorial Hosp., 862 F.2d 1299, 1303 (7th Cir. 1988) ("Judges must have at heart the interests of other litigants in future cases, and hold them equal in weight with the interests of today's.").

257 Cf. Fiss, supra note 8, at 1075 ("I do not believe that settlement as a generic practice is preferable to judgment or should be institutionalized on a wholesale and indiscriminate basis. It should be treated instead as a highly problematic technique for streamlining dockets.").

25878 T.C. 350 (1982), aff'd, 820 F.2d 1220 (4th Cir. 1987).

259 See Smith Transcript at 10-11.

As Your Honor knows better than I do, the Court is being inundated with petitions. When I became admitted to this Court; which was about eight years ago; it was normal to have 8,000 or 9,000 cases a year. I believe that it's no overstatement to say that this year approximately 20,000 cases will be docketed ....

And what [Smith and Jacobson] have done is they have induced the Respondent and the Court to waste its [sic] time . . . .

This court will now-as a result this Court will now be the recipient of hundreds or thousands of domestic silver straddle cases which there's no prospect of resolving. I think at this point it's interesting-the Court should consider that we spent about six months getting this case ready for trial ....

There are 13 cases docketed before the Court with similar issues. If we devote our energies to those court cases and it happens again, there's no doubt that two years down the road we could be in the same situation and the Court will now have 3,000 domestic silver straddle cases. 
Are we going to gear up for trial after trial on a case by case basis, and have Merrill Lynch coming in at the eleventh hour getting rid of the case?

We simply can't operate that way, counsel. We've got 36,000 petitions pending in the Tax Court today. We can't spend all this time. You know perfectly well how much time the Court has spent. ${ }^{260}$

Yet Smith is unusual; courts generally espouse favoring settlement, not trial. ${ }^{261}$

The key to understanding the focus on docket congestion may not actually be the effects on litigants but instead on the judges themselves: docket congestion affects judges because busy trial calendars increase judges' workloads. ${ }^{262}$ Judges' desire to decrease their workload is a plausible explanation for courts' willingness to encourage settlement. ${ }^{263}$ Judge Sarokin states, "The judiciary had developed a siege mentality because of the size of its calendar, and settlement rather than adjudication had become the battle cry of its members."264 In fact, Judge Sarokin takes it even farther, stating,

The arguments that lawyers and judges use to convince litigants to settle have become so standardized that they could be printed and served with the complaint:

By settling this dispute:

$260 \quad I d$. at 48.

261 See supra text accompanying note 236.

262 See Galanter \& Cahill, supra note 21, at 1364 ("There has been a tremendous push in recent years to encourage settlement with an eye to lowering the demands on courts. By definition, settlements mean there is less that courts have to do.").

263 See Fiss, supra note 8, at 1086. ("I recognize that judges often announce settlements not with a sense of frustration or disappointment, as my account of adjudication might suggest, but with a sigh of relief. But this sigh should be seen for precisely what it is: It is not a recognition that a job is done, nor an acknowledgment that a job need not be done because justice has been secured. It is instead based on another sentiment altogether. Namely, that another case has been 'moved along,' which is true whether or not justice has been done or even needs to be done. Or the sigh might be based on the fact that the agony of judgment has been avoided."); $c f$. Richard A. Posner, What Do Judges and Justices Maximize? (The Same Thing Everybody Else Does), 3 Sup. CT. ECON. Rev. 1, 21 (1993). If, by contrast, judges were paid by the number of cases they tried, they would have an incentive to discourage settlement unless settlements attracted more "business" in the form of cases filed there, instead of in another court, that would go to trial. If they were paid by the number of suits resolved, they might have an incentive to encourage settlement, in order to resolve more cases in a given time period. Cf. Willis L.M. Reese, The Contractual Forum: Situation in the United States, 13 AM. J. CoMP. L. 187, 188-89 (1964) (asserting that historical hostility to forum-selection clauses may partly be explained by judges being paid by the case).

264 Sarokin, supra note 1 , at 432. 
1. You save the cost of litigation.

2. You avoid the time, irritation, and emotion of a trial.

3. If you are the recipient of money, you will have its immediate use.

4. If you are a payor, you avoid the possibility of a larger verdict.

5. All uncertainties are eliminated-no one in a trial knows what the final outcome will be.

6. The best result is a settlement with which no one is completely satisfied. ${ }^{265}$

Thus, judges' incentives to encourage settlement combine with the general concept of resolving disputes peacefully, resulting in favoritism of settlement. Parties generally have no incentive to push for trial in the face of encouragement of settlement because, as discussed above, they bear the litigation costs. ${ }^{266}$ Absent a litigation subsidy, parties who had reached an agreement in principle would be unlikely to continue litigating even if encouraged to do so. ${ }^{267}$

\section{B. Is Precedent "Manipulation" Through Settlement Objectionable?}

The discussion in Section A, above, reveals a backdrop of preference for settlements over trials. Yet, the preference is weakened when third parties who are otherwise uninvolved in the litigation, particularly interest groups, have sought settlements of court cases for their own reasons. Commentators may point out that this kind of settlement allows "manipulation" of precedent, which is true. The current system certainly permits manipulation of precedent through settlement engineering, as in Piscataway; there is no remedy for those opposed to the Piscataway settlement, and no mechanism for reinstating the case on the Court's docket. Yet any settlement alters the content of precedent in a non-random way. ${ }^{268}$ Should the intention to influence precedent alter the permissibility of settlement? This Section compares Piscataway and Smith in an attempt to answer the question

265 Id. at 432-33. But of. Lauren K. Robel, Grass Roots Procedure: Local Advisory Groups and the Civil Justice Reform Act of 1990, 59 BROOK. L. REv. 879, 905 n.144 (1993) ("For this section, I excluded comments from judges. This one was typical, however: "The [Givil Justice Reform Act] was well-intentioned, but based on two false premises: [one of which is that] docket problems are the result of lazy federal judges (I work harder now than when I was a lawyer).' ").

266 See supra note 5 and accompanying text.

267 No one should be forced to litigate against his will. Cf. Fiss, supra note 8, at 1085 (arguing that parties should not be forced to commence litigation). But see Smith Transcript (requiring taxpayer couples to continue litigating despite their expressed desire to concede the case).

268 See supra text accompanying note 48. 
of whether third-party manipulation of precedent through settlement is objectionable.

\section{Third-Party Manipulation in Piscataway}

What is wrong with interest group financing of settlements? At first glance, interest group financing of the Piscataway settlement is analogous to interest group financing of test cases, discussed above. ${ }^{269}$ However, one difference between these situations is that in Piscataway Ms. Taxman herself received the portion of the settlement that did not go to her lawyer, whereas in test cases, the plaintiff receives from the interest groups only financial assistance in the litigation; any payment to the plaintiff in test cases normally will come from the defendant. Nothing prevents interest groups from providing financial support to the plaintiff during the litigation. ${ }^{270}$ However, Ms. Taxman presumably was not someone the Black Leadership Forum was interested in helping; the payoff to Ms. Taxman was made by groups that substantively disagreed with her position and were trying to "buy off" the litigation to avoid a precedent, ${ }^{271}$ rather than trying to advance Ms. Taxman's cause. Yet it is not as if the civil rights groups bribed the Piscataway school board or its members to vote to settle a case they were actually eager to litigate. Instead, the money provided by interest groups was paid to Ms. Taxman, the plaintiff, and her attorney. Ms. Taxman and the school board settled their dispute by mutual agreement, and the taxpayers of Piscataway Township were spared the full burden of the settlement. If the interest groups had been precluded from contributing to the settlement, it might have meant that the local taxpayers would simply have borne a larger share. ${ }^{272}$

The fact that Ms. Taxman arguably was "bought off" by the civil rights groups raises the point that Ms. Taxman was in a position to reject the settlement if she objected to the means by which the Piscataway school board financed it. In fact, she could even have agreed to settle with Piscataway Township only on the condition that the settlement not be funded by interest groups. This reveals that no one, other than the parties to Piscataway, had the right to put conditions on the terms of the settlement. In our litigant-controlled system, ${ }^{273}$

269 See supra notes 104-06 and accompanying text.

270 See supra text accompanying note 104.

271 See supra text accompanying notes 149-51.

272 Of course, it is possible that the case would not have settled without the intervention of the civil rights groups. But since it is the parties' right to agree to settle a case, the fact that money towards the settlement was provided by third parties, with no strings attached, does not seem objectionable.

273 See Zellar, supra note 18, at 871. 
only the parties can determine what terms of a settlement are acceptable or unacceptable to them. In effect, Ms. Taxman was in the position of protecting the principle for which she was suing, so she was in a position to name the price for which she would compromise that principle. Piscataway therefore represents what is perhaps a side effect of the adversarial system of case resolution. The system works because of the parties' incentives; the interests of non-parties are not represented despite the externalities, such as precedent or lack of precedent.

Assuming for the moment that the Piscataway settlement was nonetheless objectionable, there are two theoretically possible ways to prevent such situations from arising in the future. One would be to prohibit interest group financing of settlements. This might prevent some settlements, which conflicts with the general policy in favor of settlement. However, in this context, the public value of precedent might outweigh the policy in favor of settlement. Yet it seems unlikely that such a law would be enforceable. In fact, any third party contribution to a settlement is analogous to interest-group contributions because in any such situation, the contributing party has an interest of its own it is attempting to further through the contribution. ${ }^{274}$

Another tack to prevent the recurrence of situations like the one in Piscataway would be to adopt Chief Justice Rehnquist's approach to mootness doctrine, viewing it as merely guided by Article III, not mandated, so that the Supreme Court could or would hear all cases settled after the grant of certiorari. ${ }^{275}$ However, such a rule seems overbroad when Piscataway is looked at as the impetus. No one cried out for prohibition of settlement of docketed Supreme Court cases when Bon-

274 Piscataway provided an easier case in which to engineer a settlement than some employment discrimination cases because only monetary damages were at issue; Ms. Taxman had been reinstated after a two-year hiatus. See Linda Greenhouse, Affirmative Action Settlement: The Overview, N.Y. TmEs, Nov. 22, 1997, at A1. The settlement was only for the back pay and fringe benefits the District Court had ordered, plus interest, not for punitive damages or emotional distress damages.

275 See Honig v. Doe, 484 U.S. 305, 330 (1988) (Rehnquist, G.J., concurring) ("Such a rule would likely have three effects: (1) The number of petitions for certiorari might decline slightly, as parties and their attorneys become aware of the obligation and liability to see the case through to decision; (2) it would likely discourage settlements after certiorari had been granted, since the settlement would be meaningless (assuming a Court decision post-settlement would apply to the parties too, not just as precedent for third parties); and (3) it might encourage settlements between the time of the petition for certiorari and the decision on the petition."). 
ner Mall ${ }^{276}$ was settled. True, Piscataway might have had farther-reaching implications, but the main cause of the outcry about the settlement was the financial contribution of an interest group. ${ }^{277} \mathrm{Re}-$ quiring docketed Supreme Court cases to go forward would not prevent interest-group financing of settlements at the court of appeals or state supreme court levels, for example.

Chief Justice Rehnquist's approach would also require parties to litigate a case both sides wish to drop. ${ }^{278}$ This raises reasons to dismiss the case that are at least as compelling as the potential value of the precedent. The parties would be subsidizing the precedent without any real benefit to them. ${ }^{279}$ This is worse even than Smith, where only one litigating party was subsidizing precedent against his will. Even worse, when the parties are no longer adversarial, they will no doubt not develop their positions as much or litigate as forcefully, ${ }^{280}$ affecting the court's ability to make an informed decision.

\section{Third-Party Manipulation in Smith}

As it happens, the Smith precedent was not a particularly important one. Smith was superseded by statute soon after it was decided, ${ }^{281}$ so it has rarely been cited for its substantive holding on tax strad-

276 See U.S. Bancorp Mortgage Co. v. Bonner Mall Partnership, 513 U.S. 18, 20 (1994). That case settled after the Supreme Court granted the petition for a writ of certiorari and was briefed on the merits of the case. See supra note 91.

277 See supra note 165.

278 Cf. Fiss, supra note 8, at 1085 (stating that parties should not be forced to commence litigation).

279 That is, generally a person will incur the costs of litigation, rather than fail to bring suit or settle a lawsuit that has been brought, because the expected value to that person is greater than the expected value of the alternatives. See supra note 51 and accompanying text.

280 See Gail S. Coleman, Overcoming Mootness in the H-2A Temporary Foreign Farmworker Program, 78 GEo. L.J. 197, 217 (1989) ("Moot disputes, often of little importance to either party, are seldom argued with the zeal or passion of adversaries in a live dispute."); Lee, supra note 35, at 668 ("A proceeding between litigants who lack a truly adversarial posture is far less likely to produce a high quality decision than a proceeding between genuinely hostile litigants.").

281 See Pub. L. No. 98-369, § 108, 98 Stat. 630 (1984) (amended 1986) (enacted by the Tax Reform Act of 1984); see also Miller v. Commissioner, 84 T.C. 827, 842 (1985) ("The legislative history makes it clear that Congress was aware of the Commissioner's litigating position on straddles and of our decision in Smith v. Commissioner, 78 T.C. 350 (1982).”). In 1986, Congress amended $\S 108$ of the 1984 Act to clear up conflicting interpretations. See Pub. L. 99-514, $§ 1808$ (d), 100 Stat. 2817; Tway v. Commissioner, 63 T.C.M. (RIA) 212 (1993). 
dles. 282 Congress would likely have acted even without the Smith decision, because the IRS continued to litigate the issue post-Smith. ${ }^{283}$ In fact, another case would likely have made it to Tax Court shortly afterwards, particularly because thousands were pending at the IRS, ${ }^{284}$ and eventually one of these cases would have been tried.

In effect, the Tax Court in Smith required the Smiths, the Jacobsons, and the IRS to bear the burden of litigation that was relevant to the IRS and third parties, but not to the Smiths or the Jacobsons. As discussed above, generally parties who had reached an agreement in principle would be unlikely to continue litigating even if encouraged to do so because of the value of the potential precedent, absent a subsidy of their litigation costs. The Tax Court did not subsidize the Smiths' and the Jacobsons' costs. The Smiths and the Jacobsons continued to litigate only because the Tax Court required them to do so, eliminating their autonomy to concede the case. Yet third parties benefitted because precedent is a public good. ${ }^{285}$ In contrast to Smith, Ms. Taxman's settlement with the Piscataway school board preserved her autonomy to decide that she preferred a settlement, even if the settlement was funded by non-parties with interests adverse to hers to continued litigation. ${ }^{286}$

\section{CONCLUSION}

Even without outside encouragement, the most likely outcome of any dispute is settlement before trial, simply because each party has an

282 See, e.g., Kirchman v. Commissioner, 862 F.2d 1486, 1494 (11th Gir. 1989) (citing Smith for proposition that Tax Court must examine the entire transaction); Polakof v. Commissioner, 820 F.2d 321, 324 n.6 (9th Cir. 1987) (citing Smith for proposition that subjective intent at time taxpayer entered transaction is determinative of profit motive); Dewees v. Commissioner, 870 F.2d 21, 35 (1st Gir. 1982) (citing Smith for proposition that uncorroborated testimony that transaction was entered into for profit lacks probative value); United States v. Atkins, 661 F. Supp. 491, 495 (S.D.N.Y. 1987), aff'd, 869 F.2d 135 (2d Cir. 1989) (citing Smith for proposition that existence of profit motive is a fact question on which taxpayer bears burden of proof). But of. Tway v. Commissioner, 63 T.C.M. (RIA) 212 (1993); Stoller v. Commissioner, 59 T.C.M. (P.H.) 659 (1990); Miller v. Commissioner, 84 T.C. 827 (1985), rev'd, 836 F.2d 1274 (10th Cir. 1988).

283 See supra note 198.

284 See supra note 261. In fact, at one point in 1984, 4400 cases involving pre-1981 commodity straddles were docketed in the Tax Court. See Landreth, 859 F.2d at 645 n.4.

285 See supra note 45 and accompanying text.

286 In fact, Ms. Taxman may have been quite happy to take money away from an interest group that advanced interests that may indirectly have led to her layoff. 
economic incentive to settle. ${ }^{287}$ In part, this Article has sought to explain our general policy in favor of settlement, as such a policy appears superfluous. The Article has pointed out that courts have an incentive to encourage settlement-namely, reducing their workloads. Scholarly encouragement of furtherance of settlement is therefore unnecessary unless it helps litigation parties find a settlement range. Even then, settlement is only valuable if the increase in the parties' and court's aggregate welfare is not more than offset by the reduction in the welfare of the taxpaying public who benefits from precedents.

The benefits of precedent are often overlooked in discussions about settlement, perhaps because of the inherent bias of the "dispute resolution" model of litigation, which views precedent as a side effect of resolving the parties' dispute. One positive effect of the controversy over the Piscataway settlement is that it raised awareness of the effect of settlement on the content of case law precedent. In fact, public reaction to the Piscataway settlement, which included objection to "docket manipulation," reveals the importance of the dispute resolution view in the tendency to encourage settlement.

Precedent has public value, and its content is altered by settlements. In fact, settlement is nonrandom, so even settlements made with no thought of the effect of the settlement on a body of precedent influence the substantive content of the body of precedent. Settlement, or refusal to settle, can also be a conscious manipulation of precedent. Because precedent is path-dependent, interest groups can manipulate the substance of a body of case law by choosing to bring and not to settle cases with favorable facts, and by engineering settlements in unfavorable cases, as the civil rights groups did in Piscataway.

Settlement is an integral part of our justice system, which provides litigation parties with autonomy in the decision whether to settle a case. ${ }^{288}$ Therefore, we have to at least tolerate settlement, despite its alteration of the content of precedent. Intentional engineering of a settlement might seem to differ from party autonomy, since it involves a third party. However, no third party can engineer a settlement without the agreement of the litigation parties. Smith is a good example of that; Merrill Lynch put up the money, but the IRS refused to settle

287 See supra notes 50-61 and accompanying text.

288 See Cordray, supra note 20, at 9 ("American law treats the settlement agreement as a member of the larger family of private contracts."); see also Zellar, supra note 18, at 871 ("[L]itigation is party-initiated and party-controlled."); Galanter \& Cahill, supra note 21, at 1371 (1994) ("[Settlement] . . involves a process of compromise in the sense that each has sacrificed some part of his claim in order to secure another part."). 
with the taxpayers. Thus, even in the third-party interest-group context, settlement is a matter of party autonomy. Forcing parties to litigate in spite of a desire to settle does not mesh with the principles underlying the adversary system. Even in Smith, where one party did want to continue litigating, overriding the other party's autonomy to concede the dispute was a costly way to develop precedent.

Smith is of course an exceptional situation. Even the Tax Court does not normally require non-adverse parties to continue litigating. The justice system would grind to a halt if cases were prohibited from settling. Even with the small percentage of disputes that result in precedent, numerous cases are decided each year, adding to the body of precedent. Perhaps Piscataway might have been one of them, had not the civil rights groups contributed financially to the settlement. We will never know-settlement happens. 
